\title{
Energy Flow through the Marine Ecosystem of the Lancaster Sound Region, Arctic Canada \\ HAROLD E. WELCH, ${ }^{1}$ MARTIN A. BERGMANN, ${ }^{1}$ TIMOTHY D. SIFERD, ${ }^{1}$ KATHLEEN A. MARTIN, ${ }^{1}$ MARTIN F. CURTIS, ${ }^{1}$ RICHARD E. CRAWFORD, ${ }^{1}$ ROBERT J. CONOVER ${ }^{2}$ and HAAKON HOP ${ }^{3}$
}

(Received 24 June 1991; accepted in revised form 1 April 1992)

\begin{abstract}
This paper synthesizes the trophic dynamics of a Canadian arctic marine ecosystem in so far as it is known, using new data on primary production, zooplankton, the bivalve Mya truncata, and arctic cod (Boreogadus saida), as well as literature values for marine mammals and seabirds. The $98000 \mathrm{~km}$ region has a high rate of primary production relative to other parts of arctic Canada. About $60 \mathrm{~g} \mathrm{C} \cdot \mathrm{m}^{-2}$ are fixed annually, of which approximately $90 \%$ is contributed by phytoplankton, $10 \%$ by ice algae, and $1 \%$ by kelp. Phytoplankton production is twofold higher along the south coast of Cornwallis Island than elsewhere in Barrow Strait. Four copepod species, of which Pseudocalanus acuspes is the most important energetically, graze about one-third of the phytoplankton production. Bivalves maintain high biomass but low energy flow, acting as sedimenting agents. Arctic cod is a major component, with 125000 tonnes being consumed by marine mammals and 23000 tonnes by seabirds annually. Our hydroacoustic estimate for mean arctic cod density, $0.0022 \mathrm{fish} \cdot \mathrm{m}^{-2}$, is probably too low, partly because we have been unable to quantify dense aggregations of schooling fish. The ecological efficiency of ringed seal is near maximum, with $5 \%$ of ringed seal ingestion going to bears and man as seal flesh. The data on total kill and prey consumption in whales and birds is incomplete because they migrate out of the Lancaster Sound region in winter. The food chain is very long, with bears occupying the fifth trophic level; this is reflected by high biomagnification factors for persistent lipophilic pollutants such as PCBs. There are major data gaps for some zooplankton and most of the benthos, as well as for winter populations and energetics. This trophic analysis is therefore incomplete and efficiencies for entire trophic levels cannot be calculated.
\end{abstract}

Key words: seals, whales, seabirds, benthos, zooplankton, phytoplankton, primary production, secondary production, harvest, yield

RÉSUMÉ. Cet article résume la dynamique trophique de l'écosystème marin dans le Canada arctique dans la mesure où il est connu, en utilisant de nouvelles données sur la production primaire, le zooplancton, le bivalve Mya truncata, et la morue polaire (Boreogadus saida), ainsi que les valeurs trouvées dans la documentation sur les mammifères et les oiseaux marins. Cette région d'une superficie de $98000 \mathrm{~km}^{2}$ possède un taux élevé de production primaire par rapport à d'autres parties du Canada arctique. Environ $60 \mathrm{~g} \mathrm{C} \cdot \mathrm{m}^{-2}$ sont fixés annuellement, dont environ $90 \mathrm{p}$. cent par le phytoplancton, 10 p. cent par les algues glaciaires et $1 \mathrm{p}$. cent par les laminaires. La production de phytoplancton est deux fois plus élevée le long de la côte méridionale de l'île Cornwallis qu'ailleurs dans le détroit de Barrow. Quatre espèces de copépodes, dont la Pseudocalanus acuspes est la plus importante du point de vue énergétique, utilisent environ un tiers de la production de phytoplancton pour se nourrir. Les bivalves contribuent de façon importante à la biomasse mais peu au flux énergétique, étant des agents de sédimentation. La morue arctique est une composante importante, étant consommée au taux annuel de 125000 tonnes par les mammiferes marins et de 23000 tonnes par les oiseaux marins. Notre estimation hydroacoustique pour la densité moyenne de la morue arctique, 0,0022 poissons $\mathrm{m}^{-2}$, est probablement trop faible, en partie parce que nous avons été incapables de quantifier les regroupements denses des poissons se rassemblant en bancs. L'efficacité écologique du phoque annelé est proche de son maximum, 5 p. cent de l'ingestion de cet animal allant à l'ours et à l'homme sous forme de chair de phoque. Les données sur le nombre d'animaux tués et sur la consommation de proies chez les baleines et les oiseaux sont incomplètes en raison de leur migration hivernale à l'extérieur du détroit de Lancaster. La chaîne alimentaire est très longue, les ours occupant le cinquième niveau trophique; cela se traduit par des facteurs de bioamplification élevés en ce qui concerne les polluants lipophiles persistants tels que les BPC. Il existe des lacunes dans les données pour certains éléments du zooplancton et pour la plupart du benthos, ainsi que pour les populations et l'énergétique hivernales. Cette analyse trophique est donc incomplète et il n'est pas possible de calculer l'efficacité pour l'ensemble des niveaux trophiques.

Mots clés: phoques, baleines, oiseaux marins, benthos, zooplancton, phytoplancton, production primaire, production secondaire, prélèvement, rendement

Traduit pour le journal par Nésida Loyer.

\section{INTRODUCTION}

Our overall objective in this paper is to quantify the trophic dynamics of the Lancaster Sound region (LSR) marine ecosystem (Fig. 1). The LSR is important because it is used intensively by many marine mammal and seabird populations in the eastern Arctic, and it supports several Inuit communities. It is also of industrial importance because it forms the eastern part of the Northwest Passage, includes two heavy metal mines, and is a potential source of hydrocarbons. For these reasons, and because regular aircraft and ship service to Resolute provides easy access to the area, the LSR has been better studied than other parts of the Canadian Arctic, although in an absolute sense it still remains a poorly understood ecosystem.

We expect that a model of the ecosystem energy flow will help define the food supplies of marine mammals and seabirds and will form a basis for assessing marine mammal exploitation.
Also, pollutants originating far to the south are occurring in arctic carnivores in significant concentrations (Muir et al., 1988; Norstrom et al., 1988), and the dynamics of these contaminants can only be understood in the context of the food web and energy flow. Some idea of the trophic dynamics of a system - "who eats whom and how many" - is also essential to an understanding of the biology of that system. For these reasons we have pieced together what is currently known about the trophic dynamics of the LSR marine ecosystem.

\section{Description of the Study Area}

The LSR is considered herein to constitute about 98000 $\mathrm{km}^{2}$ of sea surface (Fig. 1; Table 1). Ocean currents are dominated by southward and eastward flow out of the Polar Basin into Baffin Bay via Barrow Strait, McDougall Sound, Wellington Channel, and Lancaster Sound (summarized from Fissel $e t$

\footnotetext{
${ }^{1}$ Department of Fisheries and Oceans, Central and Arctic Region, Freshwater Institute, 501 University Crescent, Winnipeg, Manitoba, Canada R3T 2N6

${ }^{2}$ Department of Fisheries and Oceans, Bedford Institute of Oceanography, Dartmouth, Nova Scotia, Canada B2Y 4A2

${ }^{3}$ Department of Zoology, University of Alberta, Edmonton, Alberta, Canada T6G 2E9

(C) The Arctic Institute of North America
} 


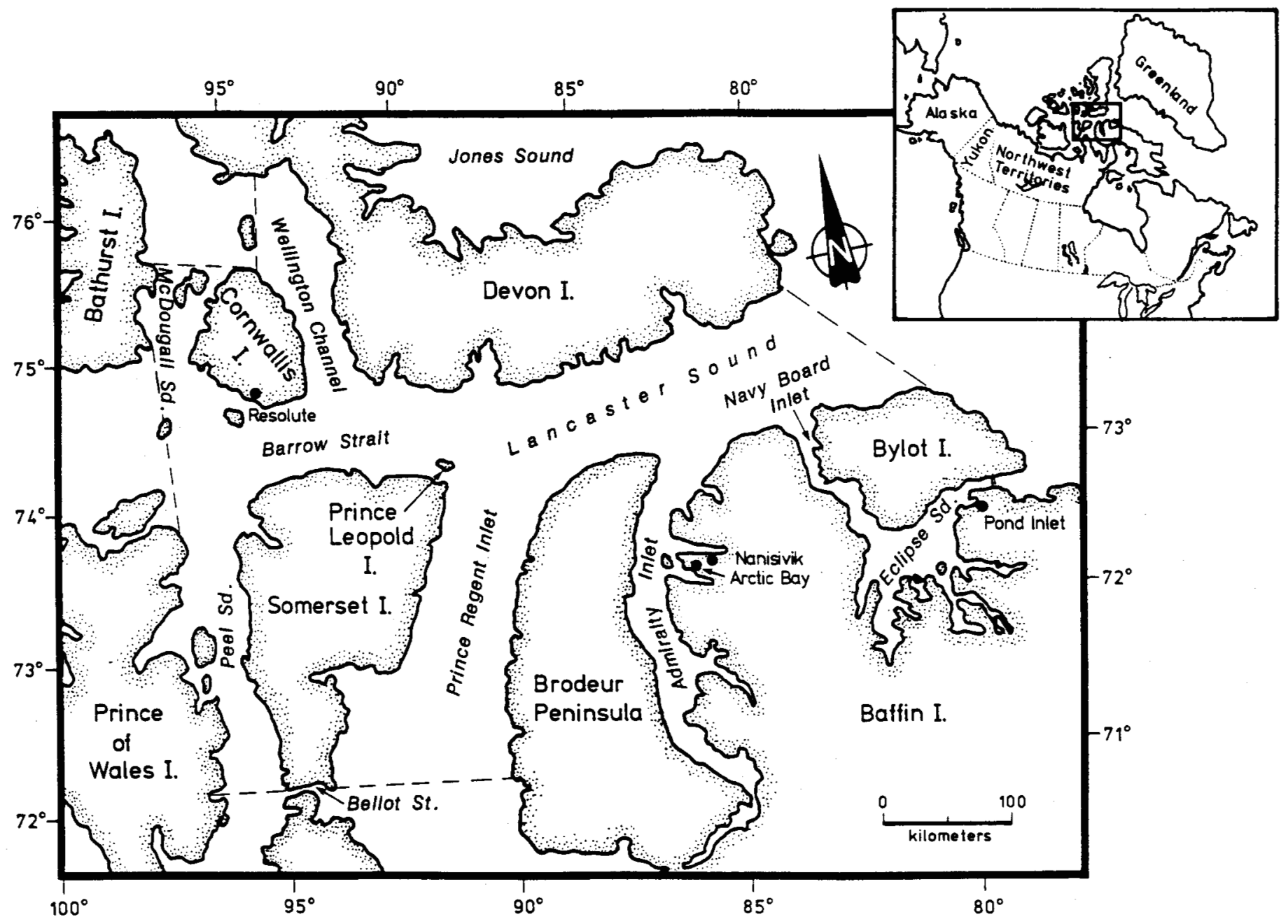

FIG. 1. Place-names in the Lancaster Sound region (LSR), arctic Canada. The LSR is defined by the dashed lines for the purposes of this paper.

al., 1982; Gorman, 1988; Leblond, 1980; Marko, 1978; Prinsenberg and Bennett, 1987). Narrow counter currents are found going northward on the east side of channels oriented north-south and going westward on the north side of Parry Channel along the south coasts of Devon and Cornwallis islands (Leblond, 1980). The counter-clockwise current in north Baffin Bay gives rise to large eddies at the mouth of Lancaster Sound (Fissel et al., 1982) (Fig. 2). The western end of Barrow Strait is a relatively shallow sill of $150 \mathrm{~m}$ depth, with deeper water in the surrounding channels and particularly eastward toward Baffin Bay (Fig. 2). The sill constricts the

TABLE 1. Areas of water bodies in the Lancaster Sound region

\begin{tabular}{lr}
\hline \hline Water body & Area $\left(\mathrm{km}^{2}\right)$ \\
\hline Barrow Strait (BS) & 17338 \\
Lancaster Sound (LS) & 26335 \\
Peel Sound (PS) & 9600 \\
Prince Regent Inlet (PRI) & 19103 \\
Wellington Channel (WC) & 7593 \\
McDougall Sound (McS) & 4327 \\
Admiralty Inlet (AI) & 8557 \\
Eclipse Sound (ES) & 3514 \\
Navy Board Inlet (NBI) & 1331 \\
Total Lancaster Sound Region (LSR) & 97698 \\
\hline \hline
\end{tabular}

eastward flow, resulting in turbulence and complex water movements in the downstream portion of Barrow Strait, where water masses enter from Wellington Channel and Peel Sound (Prinsenberg and Bennett, 1987). Eastward current speeds

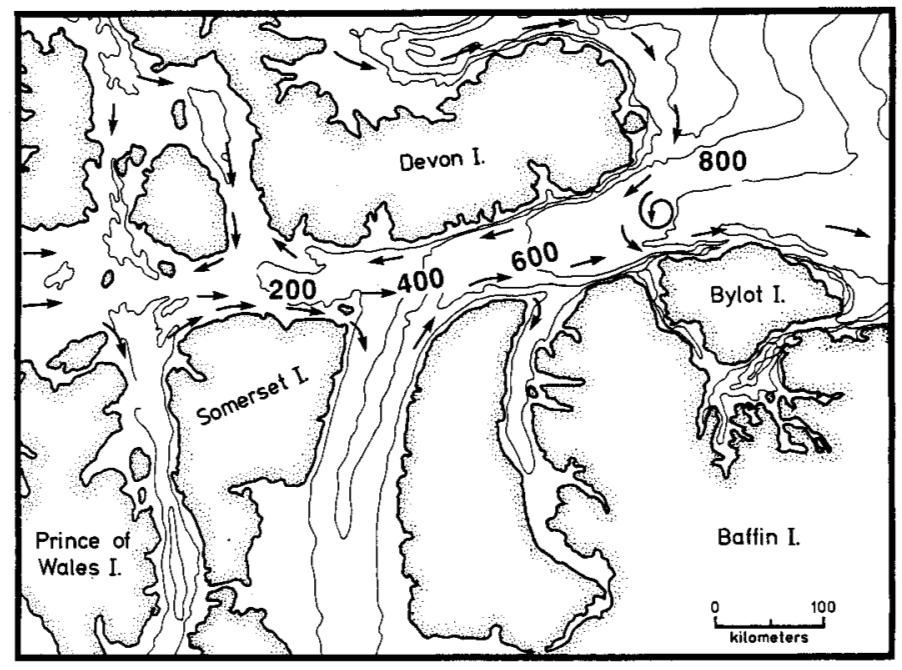

FIG. 2. Water depths (m) (after Fissel et al., 1984) and major currents (Leblond, 1980 ) in the Lancaster Sound region. 
adjacent to the northeast coast of Somerset Island are typically 30 nautical miles $(55 \mathrm{~km})$ per day (Fig. 2). Surface current velocities are probably lower in winter months (Fissel $e t$ al., 1981).

Freeze-up begins in mid-September in the bays and narrow channels and proceeds seaward, with the strong currents delaying ice consolidation in a well-established sequence from north to south and west to east (Gorman, 1988; Fig. 3). Firstyear ice dominates throughout, reaching 1.3-1.6 m thick at Arctic Bay and 1.6-1.8 m thick at Resolute by May (Marko, 1982). Ice keels and ridges are generally abundant due to high currents and numerous early winter storms. The North Water polynya of north Baffin Bay (Stirling and Cleator, 1981) extends into Lancaster Sound as a flaw lead with variable amounts of ice-free water. Depending upon the winter, the final consolidation in February or early March may leave a flaw lead as far west as Resolute, or the ice may become fast as far east as Bylot Island (Fig. 3). The ice breaks away sequentially from the eastern edge in spring, with breakup occurring at Resolute about 20 July. Birds and mammals follow the ice edge westward from Baffin Bay (e.g., McLaren, 1982; Sergeant and Hay, 1978). Ice continues to move into the LSR from the west, northwest, and southwest in August and September, at which time both first-year and multiyear ice passes through. At no time is the area completely ice free (Fig. 4).

There are four predominately Inuit communities in the area (with 1989 populations): Pond Inlet (909), Arctic Bay (554), Nanisivik (319), and Resolute Bay (164), including the outpost camp at Creswell Bay on Somerset Island (Fig. 1), consisting of a single extended family.

\section{METHODS}

\section{Ecosystem Energy Flow Model}

We have chosen the trophic dynamics model (Lindeman, 1942; Odum, 1968) as the framework within which to organize our observations. The trophic model compartmentalizes biotic energy flow into primary production and the subsequent

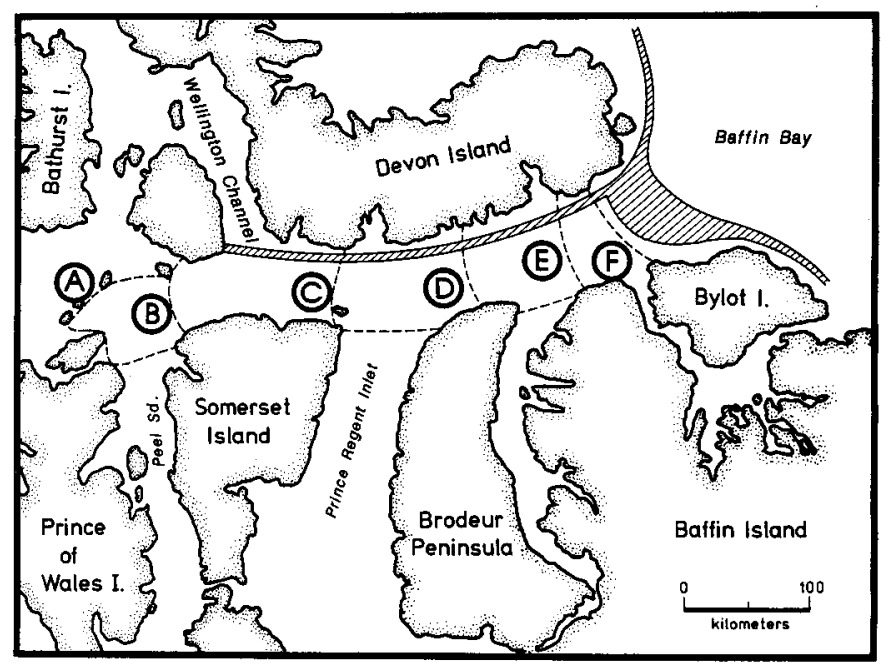

FIG. 3. Position of ice edge in Lancaster Sound-Barrow Strait in winter (after Gorman, 1988). About 50\% of the time the final consolidation in FebruaryMarch occurs at "C" (Gorman, 1988). The hatched area represents the flaw lead and polynya, an extension of the North Water polynya in north Baffin Bay (Stirling and Cleator, 1981). utilization of that energy by a series of consumers. When species $\mathrm{A}$ is ingested by species $\mathrm{B}$, which is in turn eaten by species $\mathrm{C}$, three trophic levels are present. Of the consumed animal, some is not digested (assimilated) but will be excreted and is therefore still available at the original trophic level. The rest is digested and used to perform work (metabolism) and to add bodily mass (growth), and it is growth that constitutes the input to the next trophic level.

This is a deceptively simple presentation of what is, in reality, a complex scheme for exactly detailing the hundreds of species present in any large natural ecosystem. For example, few heterotrophs feed exclusively on one trophic level, requiring the energy flow through each species to be partitioned among the trophic levels within which it operates (Burns, 1989). Nonetheless the trophic paradigm remains a useful framework for ecosystem investigation and the subsequent analysis of energy pathways. Although we speak of energy, solar radiation is the only energy flux directly measured; the rest are computed from the flows of materials (biomass, $\mathrm{O}_{2}, \mathrm{C}$, etc.) combined with data on the energy density of tissues.

Plants constitute the first trophic level, transforming solar energy into chemical potential energy, using inorganic nutrients $\left(\mathrm{N}, \mathrm{P}, \mathrm{Si}, \mathrm{CO}_{2}\right.$ and possibly $\mathrm{Fe}$ are the most important to consider in polar waters) to synthesize organic matter (carbohydrates, lipids, proteins), releasing $\mathrm{O}_{2}$ in the process. While the flux of any component can be used to estimate rates, the accumulation of biomass, the uptake of $\mathrm{CO}_{2}$, and the evolution of $\mathrm{O}_{2}$ are most commonly employed and give good agreement among each other (e.g., Irwin, 1991).

The general approach we have used for animals is to determine one-or more of the components of the energy budget for an individual: $I=G+R+E$, where $I=$ ingestion, $G=$ growth, $\mathrm{R}=$ respiratory heat loss, and $\mathrm{E}=$ excretory and egestion losses. The unknown energetics parameters can then be calculated, often using known growth and assimilation (digestion) efficiencies and assigning Ingestion a value of 100 , where: Assimilation Efficiency $(\mathrm{AE})=\frac{\mathrm{G}+\mathrm{R}}{\mathrm{I}}$ (this can also be determined directly by measurement of I and E); Gross Growth Efficiency $(\mathrm{GGE})=\frac{\mathrm{G}}{\mathrm{I}} ;$ Net Growth Efficiency $(\mathrm{NGE})=\frac{\mathrm{G}}{\mathrm{G}+\mathrm{R}}$, or $\frac{G}{A s s i m i l a t e d ~ E n e r g y ~}$. This energy budget corresponds to the "universal" model of ecological energy flow of Odum (1968). It

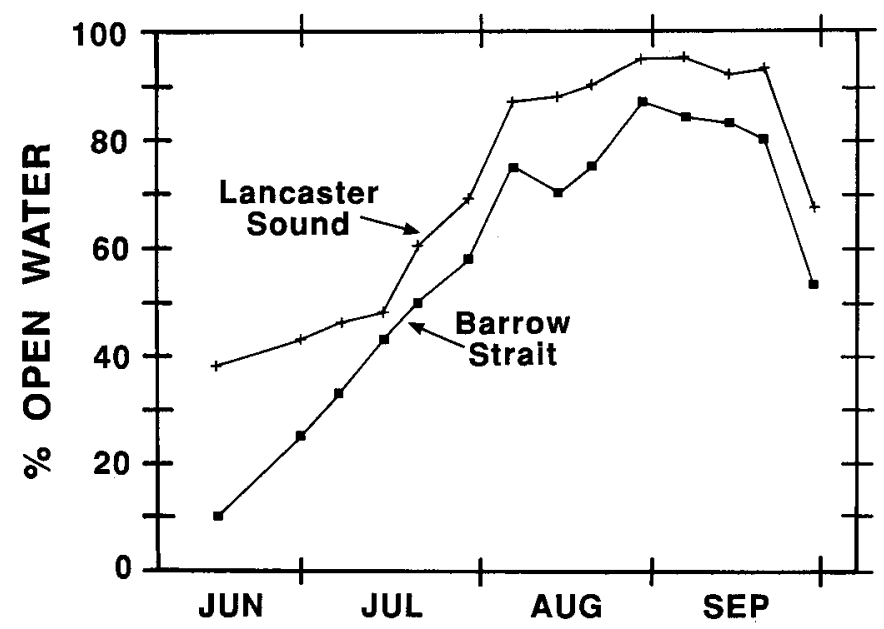

FIG. 4. Percent open water in Barrow Strait and Lancaster Sound, 6 yr mean (1982-87) compiled from weekly ice charts (Atmospheric Environment Service, Ice Forecasting Central, Ottawa). 
can be further divided (e.g., urinary energy, heat of fermentation, etc.) (Lavigne et al., 1982), but we have not done so in this paper. Energy budget components were combined with information on abundance to derive population energy flow. All data are reported per $\mathrm{m}^{2}$ of sea surface per year, then applied to whatever geographic area is appropriate. For higher vertebrates that aggregate, this means division of the total biomass by the area they occupy for a given length of time. We have used the following conversion factors: 4.1868 joules $=1$ kilocalorie; $1 \mathrm{~g} \mathrm{C}=47.7 \mathrm{~J}$ (Platt and Irwin, 1973); $1 \mathrm{~g} \mathrm{O}_{2}$ $=14.24 \mathrm{~J}$, or $1 \mathrm{~L} \mathrm{O}_{2}=20.5 \mathrm{~J}$ (Conover, 1978; Brett and Groves, 1979); dw = dry weight; ww = wet weight. To be consistent with current usage, all energy values are reported as joules, although most of the ecological energetics literature has used kilocalories until recently. Minor discrepancies due to rounding errors should be disregarded.

\section{Primary Producers}

Phytoplankton: We have used the standard short-term incorporation of ${ }^{14} \mathrm{C}$-labelled inorganic carbon into phytoplankton cells as the measure of photosynthesis. A total of 80 experimental photosynthesis-irradiance $(\mathrm{P} / \mathrm{I})$ curves were used to generate the photosynthetic parameters alpha and PBM (Fee et al., 1987; Bergmann et al., 1991), which were then combined with light at metre depth intervals to give half-hourly totals of production throughout the year using the programs of Fee (1990). Surface light data recorded by the RF1 pyranometer at Resolute (Department of Environment, Atmospheric Environment Service) was converted to quanta according to a relationship we derived empirically from comparisons with a Licor model 185 sensor, where: $\mathrm{E}=2.154$ (watts) $+44.45 ; \mathrm{n}=$ $155 ; r^{2}=0.99$. Light at depth was calculated from an empirically derived relationship between chlorophyll concentration and light extinction, where: $\mathbf{b}=0.017(\mathrm{chl})+0.092 ; \mathrm{n}=54$ (range $0.2-20 \mathrm{mg} \cdot \mathrm{m}^{-3}$ ), $\mathrm{r}^{2}=0.83$, according to Beer's Law, which predicts the intensity (I) of light at depth $z$ as: $I_{z}=I_{o} e^{-b z}$. We determined that $0.9-1.4 \mathrm{~m}$ thick first-year ice overlain by $0-0.3 \mathrm{~m}$ of water in July allowed between 1 and $5 \%$ of surface light to penetrate the water column, with less than $1 \%$ penetrating below $5 \mathrm{~m}$. We therefore assumed light to be zero (= no phytoplankton production) beneath summer ice cover, and multiplied production rates by the average percent open water (Fig. 4) to obtain area-wide rates. Chlorophyll data were collected weekly at $2,5,10,20,30,40,50,60,80$, and $100 \mathrm{~m}$ about $5 \mathrm{~km}$ south of Resolute Bay and during various cruises throughout the LSR.

Ice algae: Briefly, we developed a model that predicted the biomass of ice algae as a function of overlying snow cover and cumulative surface light for much of the Arctic (Welch and Bergmann, 1989; Welch et al., 1991). ${ }^{14} \mathrm{C} \mathrm{P} / \mathrm{I}$ curves gave photosynthetic parameters that predicted carbon uptake per unit biomass as a function of light. These two data sets were combined with surface light in half-hour intervals and a model of light transmission through snow and ice to generate daily photosynthesis using a modification of Fee's (1990) program (Bergmann et al., 1991).

Kelp: The benthic macrophyte community of Barrow Strait is dominated by the kelps Laminaria longicruris, L. solidungula, Agarum cribosum, and Alaria sp., which grow from a basal meristem where the frond joins the stipe. In October a constriction is formed that delineates subsequent frond growth, which is virtually complete by the following August (Chapman and Lindley, 1980). We determined the relationships between stipe length and annual frond dimensions and weights. In August we then randomly sampled 54 quadrats of $0.5 \mathrm{~m}^{2}$ area at $5,8,10$, and $15 \mathrm{~m}$ depths over $100 \%$ kelp cover, removing and measuring all stipes to calculate stipe and frond biomass and annual growth. These were then combined with data on percent kelp cover by depth, obtained from video photography of the 5,10 , and $15 \mathrm{~m}$ depth strata within $10 \mathrm{~km}$ of Resolute, to obtain synoptic estimates of annual kelp production. We used $12.6 \mathrm{~J}^{-\mathrm{g}^{-1}} \mathrm{dw}$ (Cummins and Wuycheck, 1971, average value for Laminaria spp.).

Herbivorous zooplankton: The biomass and life stages of the copepods Calanus hyperboreus, C. glacialis, and Pseudocalanus acuspes were monitored weekly with a $0.5 \mathrm{~m}^{2}$ vertical tow net (mesh opening $240 \mathrm{~m}$ ) about $5 \mathrm{~km}$ south of Resolute Bay. A total of 14 vertical series (in April, May, June, August, December) were analyzed for 1984, and 35 vertical series (April-September, January) were analyzed for 1986. On each date the daily respiration rate was calculated from the mean dry wt for each species in that sample as: $\log \mathrm{R}$ $=1.166-0.355 \log \mathrm{W}$, where $\mathrm{R}=\mu \mathrm{L} \mathrm{O} \cdot \mathrm{mg}^{-1} \mathrm{dw} \cdot \mathrm{d}^{-1}$, and $\mathrm{W}$ = dry wt (mg) (Conover and Cota, 1985, for mixed copepods in Wellington Channel). Mean monthly rates were calculated from daily rates and summed for the year. We have assumed an assimilation efficiency equal to 0.60 and net growth efficiency equal to 0.60 (Conover, 1978:Table 5-27; C. hyperboreus eating diatoms).

Gelatinous zooplankton: The ctenophore Mertensia ovum constituted $71.5 \%$ numerically of the gelatinous zooplankton at Resolute for the years 1985-86 (Siferd, 1990). Mertensia averaged $3.13 \mathrm{~mm}=1.17 \mathrm{mg} \mathrm{dw}$ summer, $0.63 \mathrm{mg} \mathrm{dw}$ winter; mean annual density was $402 \cdot \mathrm{m}^{-2}$ and biomass was $0.362 \mathrm{~g}$ $\mathrm{dw} \cdot \mathrm{m}^{-2}$. Respiration $=1.313 \mathrm{~L} \mathrm{O}_{2}$ summer $+0.353 \mathrm{~L} \mathrm{O}_{2}$ winter $=1.67 \mathrm{~L} \mathrm{O}_{2}$ or $34.3 \mathrm{~kJ} \cdot \mathrm{m}^{-2} \cdot \mathrm{yr}^{-1} . \mathrm{AE}=0.74$ for other ctenophores (Reeves and Walter, 1978); GGE in three studies was 2-7\%, 3 and $11 \%$, and $9 \%$ based upon carbon (Reeves and Walter, 1978); we used $8 \%$.

We assumed that the energy flow through the other $28.5 \%$ of the gelatinous zooplankton at Resolute (including the ctenophore Beroe cucumis, 5.1\%; the hydromedusae Aeginopsis laurentii, 12.1\%; and Aglantha digitale, 8.8\% (Siferd, 1990)) is proportional to that of Mertensia ovum on a numerical basis.

Parathemisto spp.: Longhurst et al. (1984) reported a mean of $170 \cdot \mathrm{m}^{-2}$ in Barrow Strait/Lancaster Sound. Hop (unpubl.) found dry weights ranging from 1.5 to $68 \mathrm{mg}$, with $4 \mathrm{mg}$ approximating medium-large animals. Respiration is estimated from Percy (1980) for $O$. affinis at $0^{\circ} \mathrm{C}$, where $\mu \mathrm{L} \mathrm{O} \cdot \mathrm{O}^{-1}=$ $0.285 \mathrm{mg} \mathrm{dw}^{0.994}$. We have used $\mathrm{AE}=0.85$ and $\mathrm{GGE}=0.37$ (summarized from Conover, 1978:Tables 5-21 and 5-27 for carnivorous marine invertebrates).

Chaetognaths: Abundance in Barrow Strait/Lancaster Sound $=1393 \cdot \mathrm{m}^{-2}$ (Sameoto, 1987; Longhurst et al., 1984); mean wet wt $=9.3 \mathrm{mg}$ wt (Sameoto, 1987:Table 2); dry:wet $w t=0.083$ for Sagitta elegans in Nova Scotia (Sameoto, 1973); respiration $8.2 \mu \mathrm{L} \mathrm{O}_{2} \cdot$ animal $^{-1} \cdot \mathrm{d}^{-1}$ for S. elegans (Sameoto, 1972); $\mathrm{AE}=0.85$ and NGE $=0.37$ (see Parathemisto above).

Ice-associated (sympagic) amphipods: Weyprechtia pinguis and Onisimus litoralis dominate the biomass of Barrow Strait in alternate years (Pike and Welch, 1990). Mean dry wt = $0.109 \mathrm{~g} \cdot \mathrm{m}^{-2}$ at $0-50 \mathrm{~m}$ depth (Pike and Welch, 1990:Table 5); 
mean dry $\mathrm{wt}=0.010 \mathrm{~g} \cdot \mathrm{m}^{-2}$ at $50-100 \mathrm{~m}$ depth (calculated from Fig. 11 in Pike and Welch, 1990); mean $=0.0050 \mathrm{~g} \cdot \mathrm{m}^{-2}$ for all of Barrow Strait/Lancaster Sound.

Respiration rate $=1 \mathrm{mg} \mathrm{O} \cdot \mathrm{g}^{-1} \mathrm{dw} \cdot \mathrm{h}^{-1}$ at $0^{\circ} \mathrm{C}$ (Lewis, 1987: Table 10 , for $W$. pinguis $)=0.0108 \mathrm{~g} \mathrm{O}_{2} \cdot \mathrm{m}^{-2}$ for 3 months beneath the ice, times $4=0.0432 \mathrm{~g} \mathrm{O}_{2} \cdot \mathrm{m}^{-2} \cdot \mathrm{yr}^{-1} . \mathrm{AE}=0.70$; NGE $=0.34$ (Lewis, 1987). O. affinis $=15.1 \mathrm{~J}^{-1} \mathrm{~g}^{-1} \mathrm{dw}$ (calculated from Percy, 1979:Fig. 2).

Benthos: Abundance estimates for the bivalves Mya truncata, Serripes groenlandicus, and Hiatella arctica were obtained by counting siphons in 2000 color photographs taken at $5,10,15$, $20,30,40,50,60,70$, and $80 \mathrm{~m}$ depth on numerous transects throughout Barrow Strait and Wellington Channel. Brittle stars and sea urchins were also counted at the same time but not classified further. Respiration and filtration rates for $M$. truncata were measured in natural seawater at $0^{\circ} \mathrm{C}$ pumped from Resolute Bay, using natural phytoplankton chlorophyll to monitor particle disappearance.

A relationship was established between siphon diameter and body size for Mya truncata from measurements on photos of individual siphons compared with the size of the same animal removed after photography. This relationship was then used to obtain a size distribution for Mya counted and measured in the survey. The size distribution seen in survey photos was approximately normal, indicating that we were unable to count small clams. We have calculated a mean soft body weight of $2.81 \mathrm{~g} \mathrm{dw} \cdot \mathrm{clam}^{-1}$ from the photos, applied against the abundance curve in Figure 5, using the density at $80 \mathrm{~m}$ for the 80-100 $\mathrm{m}$ stratum, and assuming $5 \cdot \mathrm{m}^{-2}$ for $100-200 \mathrm{~m}$, for an overall mean of 10.7 individuals $\cdot \mathrm{m}^{-2}$ or $30.1 \mathrm{~g} \mathrm{dw} \cdot \mathrm{m}^{-2}$ in Barrow Strait. The size distribution was integrated with our size-respiration and size-filtration curves to calculate those parameters.

Because the true age distribution for our sample was unknown, we were unable to compute growth directly. However, we have calculated growth for Mya truncata at Cape Hatt, north Baffin Island (Cross and Thomson, 1987). For that population: length $(\mathrm{mm})=5.102+2.335$ (age) -0.0253 (age) ${ }^{2}$ (R.H. Green, University of Western Ontario, London, unpubl. $\mathrm{ms}$.). For the same population we found a log decrease in abundance with increasing size, 5-44 $\mathrm{mm}$ size classes inclusive, where $\log _{10} Y=2.8003-0.0222 X$, where $X=$ length $(\mathrm{mm})$ and

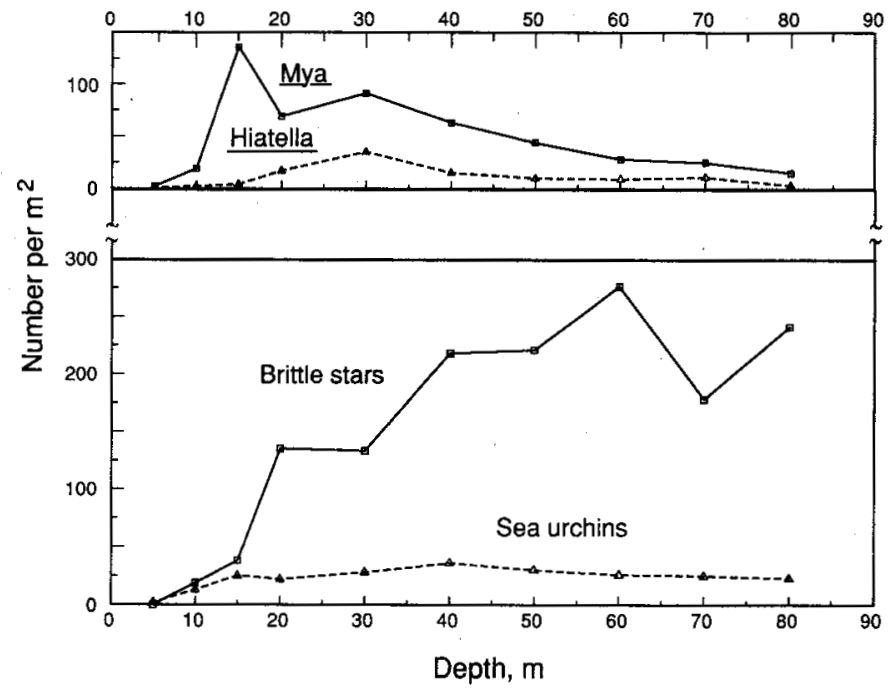

FIG. 5. Surface density of Mya truncata, Hiatella arctica, sea urchins, and brittle stars in Barrow Strait, from photographic counts.
$\mathrm{Y}=$ abundance, $\mathrm{r}^{2}=0.97, \mathrm{~N}=3397$ (calculated from Cross and Thomson, 1987:Fig. 4; using reference bay 7, and experimental bays 9-11 pre-spill). Using our own data where dry wt $(\mathrm{g})=($ age $)(0.0958)$, we have calculated the mean annual growth for Cape Hatt $M y a$ as $0.0954 \mathrm{~g} \mathrm{dw}$ per individual, times $10.7 \cdot \mathrm{m}^{-2}=1.02 \mathrm{~g} \cdot \mathrm{m}^{-2} \cdot \mathrm{yr}^{-1}$ growth when applied to Barrow Strait. We used $\mathrm{AE}=0.60$ (Bayne et al., 1989; for Mytilus edulis under low suspended sediment conditions). Wet and dry weights and energy densities are given in Welch and MartinBergmann (1990).

Arctic cod (Boreogadus saida): We used several methods to estimate the abundance of arctic cod that were either "dispersed" (i.e., scattered individuals) or in dense schools. Two of these incorporated fisheries acoustics data obtained from a system based on BioSonics dual-beam $(200 \mathrm{kHz})$ equipment (Crawford and Jorgenson, 1990). The transducer was towed at a depth of $2 \mathrm{~m}$ behind a $6.7 \mathrm{~m}$ boat and acoustic echoes were recorded on a graphic chart recorder (echogram) or in digital form on a magnetic tape for later analysis in the laboratory.

When fish were scattered, we counted marks on echograms and derived the number $\mathrm{m}^{-2}$ according to the nominal volume of the acoustic beam (Crawford and Jorgenson, 1990). When fish were in schools, precluding the discernment of individuals, abundance was estimated with echo integration following standard fisheries acoustics procedures (Johannesson and Mitson, 1983). Data editing was facilitated with graphical techniques (Crawford and Fox, 1992). Biomass was calculated assuming mean fish size of $28 \mathrm{~g}$, derived from pooled samples obtained with a bottom trawl and a gill net during the fisheries acoustic surveys.

We made visual estimates of the sizes of shallow water arctic cod schools and estimated the sizes of schools in deeper (10-30 m) water with an ordinary boat-mounted depth sounder. These data were transformed to biomass estimates (Welch, Crawford, and Hop, unpubl. data). Respiration rates were measured on arctic cod shipped from Resolute to the Vancouver Aquarium. Respiration rate at $2^{\circ} \mathrm{C}=75 \mathrm{mg} \mathrm{O}{ }_{2} \cdot \mathrm{kg}^{-1} \cdot \mathrm{h}^{-1} ; \mathrm{NGE}$ $=0.35 ; \mathrm{AE}=0.80$ (Hop, unpubl. data).

Mammals: Parameter values were obtained from personal communications and literature sources for narwhal (Monodon monoceros), beluga (Delphinapterus leucas), walrus (Odobenus rosmarus), harp seal (Phoca groenlandica), bearded seal (Erignathus barbatus), killer whale (Orcinus orca), ringed seal (Phoca hispida), and polar bear (Ursus maritimus).

Data for harp seals, ringed seals, and whales show that the basal metabolic rate (BMR) for pinnipeds and cetaceans is at or slightly below the rates predicted for terrestrial carnivores by the standard equation BMR $(\mathrm{kcal})=70 \mathrm{~W}^{0.75}$ (Kleiber, 1975), where weight $=\mathrm{kg}$, and that doubling the BMR is a close approximation of average daily metabolic requirement (ADMR) for harp and ringed seals (Gallivan, 1977; Parsons, 1977; Lavigne et al., 1982, 1986; Stewart and Lavigne, 1984; Innes et al., 1987). Digestibility of common fish foods is about $90 \%$, with a further $10 \%$ required for urinary and specific dynamic action losses, so division by 0.8 is generally appropriate (Lavigne et al., 1982). Our estimate of daily ingestion for all marine mammals was therefore ADMR/0.8.

For all marine mammals we have used $19.3 \mathrm{~J}[4.6 \mathrm{kcal}] \cdot \mathrm{g}^{-1}$ live weight. Worthy (1982) found $4.585 \mathrm{kcal} \cdot \mathrm{g}^{-1}$ live weight for an adult male harp seal with $40 \%$ blubber content. Stirling and McEwen (1975) found a mean of $4.66 \mathrm{kcal} \cdot \mathrm{g}^{-1}$ live weight for five young ringed seals ranging from 21.1 to $45.7 \mathrm{~kg}$, mean 
$41 \%$ fat content. Measurements for blubber content converge on $40 \%$ live weight for arctic seals and whales (Sergeant and Brodie, 1969; Mansfield et al., 1975; Sergeant and Hay, 1978; Lavigne et al., 1982), and walrus (Fay, 1982).

Birds: Values for parameters were obtained from literature sources for thick-billed murres (Uria lomvia), black guillemots (Cepphus grylle), northern fulmars (Fulmarus glacialis), and black-legged kittiwakes (Rissa tridactyla). Daily field metabolic rates for seabirds (Nagy, 1987) are: $\log Y=0.94+$ $0.704 \log \mathrm{W}$, where $\mathrm{Y}=\mathrm{kJ} \cdot \mathrm{d}^{-1}$ and $\mathrm{W}=$ weight in grams. Ingestion assumes 0.8 digestibility (Furness, 1978:Table 1). Our calculated ingestion rate of $1204 \mathrm{~kJ}$ for a $900 \mathrm{~g}$ bird is similar to the $1375 \mathrm{~kJ} \cdot \mathrm{d}^{-1}$ maintenance determined experimentally for slightly larger (967 g) birds (Brekke, 1989).

\section{RESULTS AND DISCUSSION}

\section{Phytoplankton Production}

Phytoplankton chlorophyll was always highest along the south shore of Cornwallis Island, decreasing rapidly south to Somerset Island and more gradually eastward into Lancaster Sound (Fig. 6). The weekly or biweekly mean chlorophyll (0-30 $\mathrm{m}$ integrated) was therefore estimated by dividing Barrow Strait into two or three horizontal strata, calculating production for each stratum separately, and adding them to get the total annual production.

We used the mean alpha and PBM for 1984-86, the 198487 mean chlorophyll, and the 1985 light to generate an average phytoplankton production of $54 \mathrm{~g} \mathrm{C} \cdot \mathrm{m}^{-2} \cdot \mathrm{yr}^{-1}$ for Barrow Strait (Table 2). We have little chlorophyll data for waters outside Barrow Strait and the south coast of Devon Island. Assuming that phytoplankton biomass in Lancaster Sound is similar to that in eastern Barrow Strait, we have estimated a mean open water chlorophyll of $60 \mathrm{mg} \cdot \mathrm{chl} \cdot \mathrm{m}^{-2}(0-30 \mathrm{~m}$ integrated $)$ for Lancaster Sound. This is similar to Borstad and Gower's (1984) estimate of $69 \mathrm{mg} \cdot \mathrm{chl} \cdot \mathrm{m}^{-2}(0-35 \mathrm{~m}$ integrated) for Lancaster Sound, obtained by remote sensing as ground truthed by ship. Using $1985 \mathrm{light}$ and percentage of open water from Figure 4, we calculated an annual production of $56 \mathrm{~g} \mathrm{C} \cdot \mathrm{m}^{-2} \cdot \mathrm{yr}^{-1}$

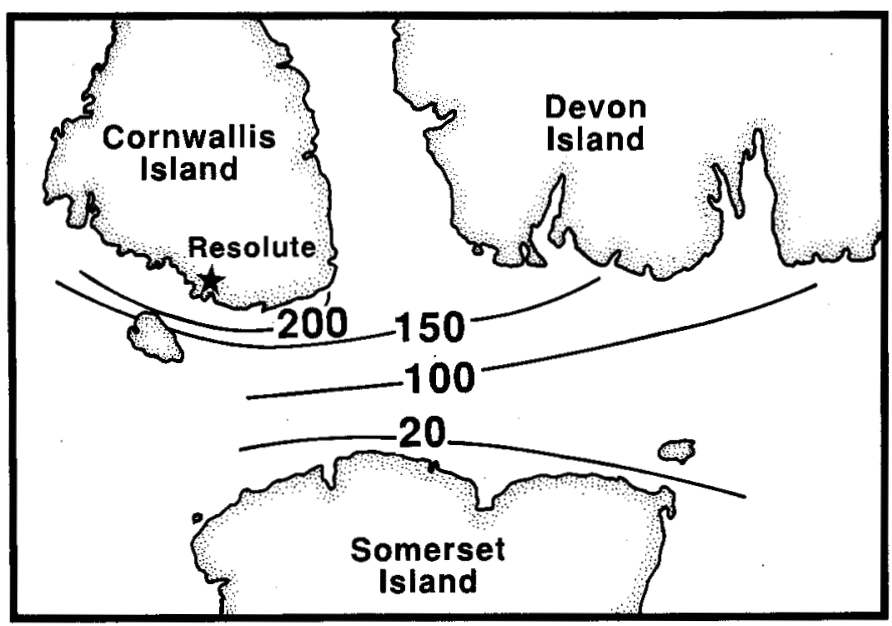

FIG. 6. Typical chlorophyll $\left(\mathrm{mg} \mathrm{chl} \cdot \mathrm{m}^{-2}\right)$ distribution during open water in Barrow Strait, integrated over 0-30 m depth. This is based upon data from various cruises during July-September 1984-89 and represents a summary of the specific chlorophyll distributions used to calculate synoptic biomass and photosynthesis.
TABLE 2. Annual phytoplankton production in the Barrow Strait area

\begin{tabular}{lc}
\hline Location & $\begin{array}{l}\text { Carbon fixed } \\
\mathrm{g} \mathrm{C}^{-2} \cdot \mathrm{yr}^{-1}\end{array}$ \\
\hline Barrow Strait, mean & 54 \\
Lancaster Sound, mean & 56 \\
Barrow Strait, 1985 & 47 \\
Barrow Strait, 1986 & 104 \\
Resolute, 1984 & 118 \\
Resolute, 1985 & 108 \\
Resolute, 1986 & 157 \\
\hline \hline
\end{tabular}

in Lancaster Sound. This is slightly higher than the $54 \mathrm{~g}$ $\mathrm{C} \cdot \mathrm{m}^{-2} \cdot \mathrm{yr}^{-1}$ for Barrow Strait, despite the lower average chlorophyll, because there is less ice and therefore more light penetration. We therefore used an average of $55 \mathrm{~g} \mathrm{C} \cdot \mathrm{m}^{-2} \cdot \mathrm{yr}^{-1}$ in the energy flow model.

In 1985, late summer (August) chlorophyll was abnormally low (Fig. 7) and early summer ice was average in Barrow Strait. In 1986 the flaw lead extended west to Resolute (" $\mathrm{A}$ " in Fig. 3), resulting in considerable photosynthesis in June, and late summer chlorophyll was normal (Fig. 7). Using year-specific P/I parameters, chlorophyll, light, and ice cover, we calculated $47 \mathrm{~g} \mathrm{C} \cdot \mathrm{m}^{-2}$ photosynthesis in 1985 compared with 104 $\mathrm{g} \mathrm{C} \cdot \mathrm{m}^{-2}$ in 1986 . We expect that these two values represent the extreme year-to-year variation for phytoplankton photosynthesis in Barrow Strait, as well as the probable range in error for our estimate of $55 \mathrm{~g} \mathrm{C} \cdot \mathrm{m}^{-2} \cdot \mathrm{yr}^{-1}$. Annual phytoplankton production is about twice as high in Resolute Passage compared to the average for Barrow Strait (Table 2), probably resulting from nutrient injection into the surface waters by the westerly coastal counter-current (Fig. 2).

\section{Ice Algal Production}

Because snow cover controls ice algal production in the Lancaster Sound region (Welch and Bergmann, 1989), synoptic estimation of production requires knowledge of snow-depth distribution, which is not yet available from remote sensing techniques. Therefore we have used our own estimates of snow cover based upon measurements made in Barrow Strait and Wellington Channel in 1984-86 (Welch and Bergmann, 1989) and used $5.0 \mathrm{~g} \mathrm{C} \cdot \mathrm{m}^{-2} \cdot \mathrm{yr}^{-1}$ for annual ice algal carbon fixation in the Lancaster Sound region (Table 3; Bergmann et

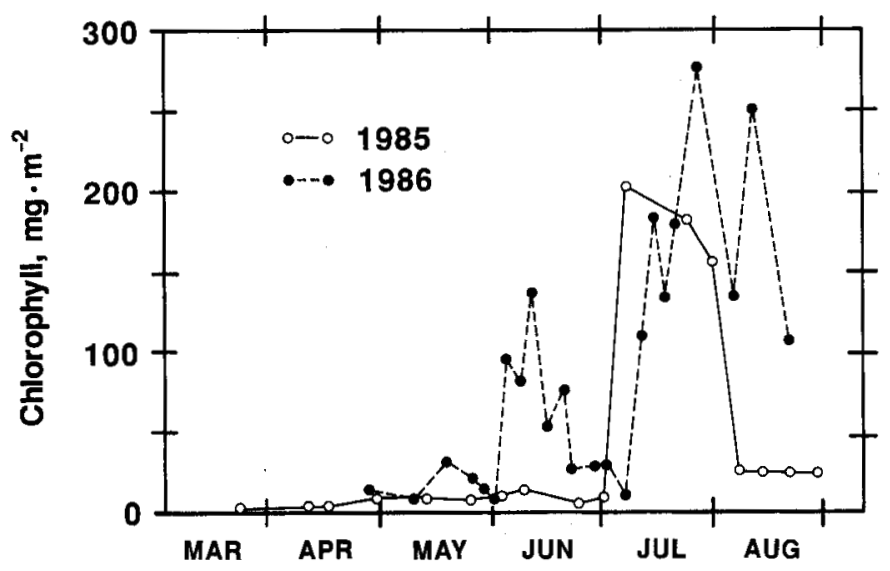

FIG. 7. Seasonal 0-30 m phytoplankton chlorophyll at a standard oceanographic station over $100 \mathrm{~m}$ depth offshore from Resolute in Barrow Strait. 
TABLE 3. Annual ice algal production integrated for four mean snow depths, Resolute area (from Bergmann et al., 1991)

\begin{tabular}{ccc}
\hline & \multicolumn{2}{c}{ Carbon fixed $\left(\mathrm{g} \cdot \mathrm{m}^{-2} \cdot \mathrm{yr}^{-1}\right)$} \\
\cline { 2 - 3 } Snow depth $(\mathrm{cm})$ & 1985 & 1986 \\
\hline \multirow{2}{*}{4.8} & 2.10 & 5.90 \\
10.1 & 1.48 & 4.20 \\
17.4 & 0.58 & 1.90 \\
21.4 & 0.31 & 1.10 \\
\hline
\end{tabular}

al., 1991). This estimate is probably within a factor of two of the actual value. It should be noted that the annual variation in surface irradiance at Resolute is not a major factor influencing the calculation of annual production, since the standard deviations for mean monthly irradiance only range from 2 to $12 \%$, increasing during the summer open water period.

\section{Kelp Production}

Annual kelp production exceeded $200 \mathrm{~g} \mathrm{dw} \cdot \mathrm{m}^{-2}$, about $1.3 \mathrm{~kg}$ $\mathrm{ww} \cdot \mathrm{m}^{-2} \cdot \mathrm{yr}^{-1}$ at $5 \mathrm{~m}$ depth and $15 \%$ dry:wet weight (Welch $e t$ al., unpubl. data) (Fig. 8). However, integrated over the entire Barrow Strait/Lancaster Sound area, the average is only $1.7 \mathrm{~g}$ $\mathrm{dw} \cdot \mathrm{m}^{-2} \cdot \mathrm{yr}^{-1}$, because the LSR has generally steep submarine slopes, with most of the bottom area below the euphotic zone.

\section{Total Primary Production}

Ice algae fix only about $10 \%$, and kelp $1 \%$, of the total primary production (Fig. 9). Phytoplankton production is somewhat higher than previous estimates for the Canadian Arctic (Subba Rao and Platt, 1984), although recent work in Jones Sound suggests that similar rates of photosynthesis occur there (Platt et al., 1987). Welch and Kalff (1975) reported a benthic respiration rate of $120 \mathrm{~g} \mathrm{O}_{2} \cdot \mathrm{m}^{-2} \cdot \mathrm{yr}^{-1}$, the equivalent of about $40 \mathrm{~g} \mathrm{C} \cdot \mathrm{m}^{-2} \cdot \mathrm{yr}^{-1}$, in Resolute Bay. The addition of planktonic respiration would raise that estimate, which adds support to the relatively high rates of primary production we have found in Barrow Strait.

\section{Ice-Associated Amphipods}

Ice amphipods are energetically insignificant when averaged over the entire area of Barrow Strait (Table 4; Fig. 9).

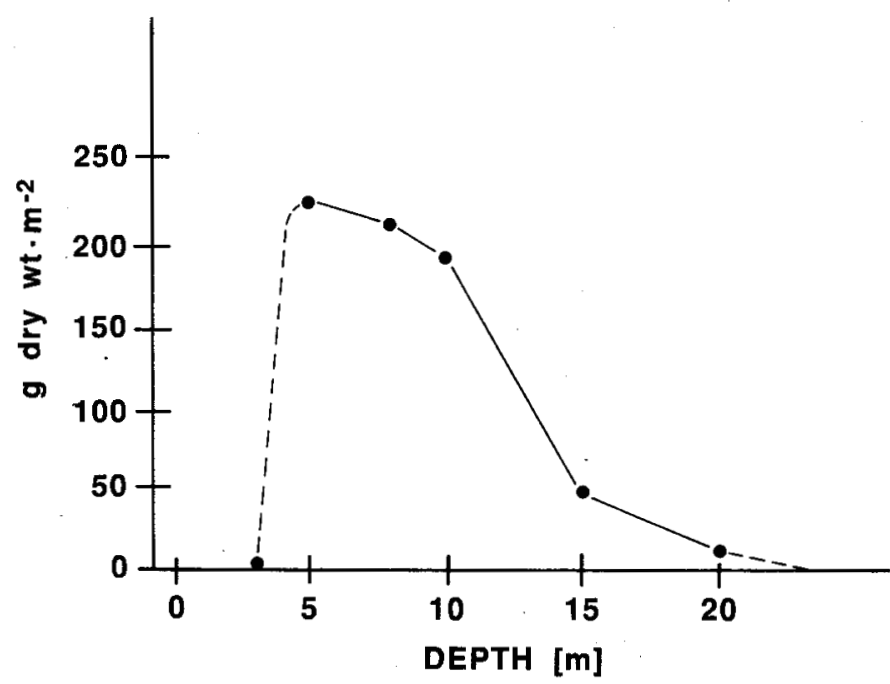

FIG. 8. Kelp biomass as a function of depth in Barrow Strait near Resolute.
Although the density of amphipods is often hundreds per $\mathrm{m}^{2}$ beneath the ice near shore in spring, abundance drops exponentially with increasing water depth and is near zero over water deeper than $50 \mathrm{~m}$ (Pike and Welch, 1990).

The amphipod species found in the Lancaster Sound region, including Apherusa glacialis, Onisimus glacialis, O. litoralis, and Weyprechtia pinguis, are known to inhabit areas that are primarily covered by first-year ice (Carey, 1985). These species are associated with the ice in winter but are members of the benthos or plankton at other times of the year (Gulliksen and Lønne, 1989). The faunal composition is different for the permanent multi-year ice of the Polar Basin, where species such as Gammarus wilkitzkii remain associated with ice year-round (Gulliksen and Lønne, 1989). There, the trophic importance of sympagic amphipods distant from shore is likely much greater than in the first-year ice of the LSR, because their mean density is higher.

\section{Zooplankton}

Four species account for nearly all the energy flow through the herbivorous copepods. Pseudocalanus acuspes is metabolically most important, followed by Calanus hyperboreus, $C$. glacialis, and Metridia longa (Table 5). In 1984 there was an extraordinarily large population of Pseudocalanus acuspes in Barrow Strait. The 1986 copepod populations appear to have been more typical, according to what we have seen, in 198391 (Conover, unpubl. data), and therefore we have used the 1986 data in the trophic model (Fig. 9). Together, the copepods eat about one-third of the phytoplankton production. The annual biomass of large Calanus fluctuates only twofold, whereas the biomass of Pseudocalanus can fluctuate tenfold (Conover, unpubl. data). Together with amphipods, large Calanus constitute the bulk of arctic cod diet (Bradstreet et al., 1986), so the large fluctuations in Pseudocalanus may have little influence on the herbivore - arctic cod - higher vertebrate food chain.

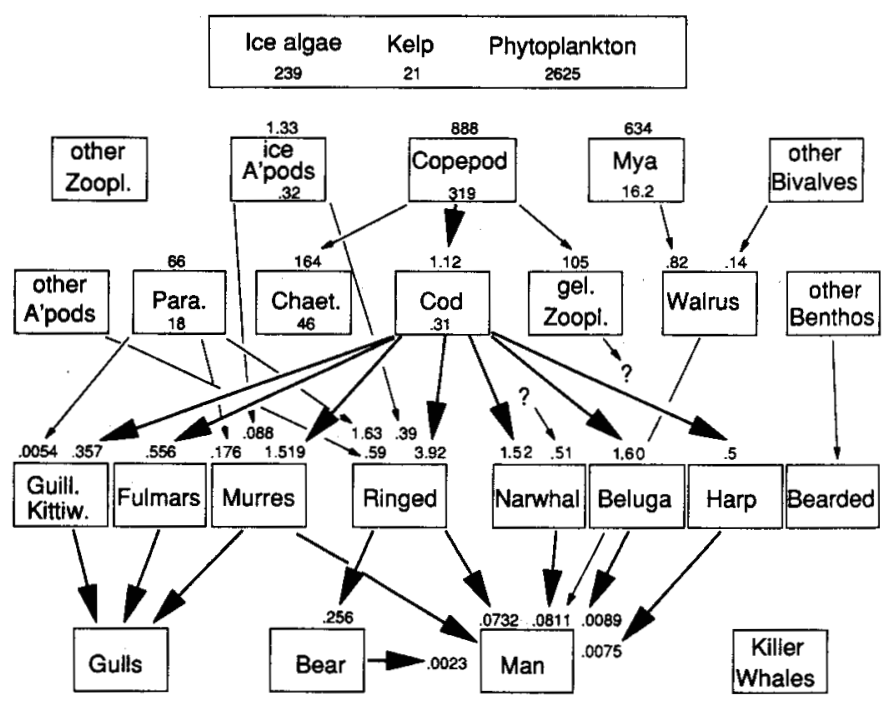

FIG. 9. Energy flow $\left(\mathrm{kJ} \cdot \mathrm{m}^{-2} \cdot \mathrm{yr}^{-1}\right)$ through parts of the marine food web, Lancaster Sound region (graphic summary of Tables 4,6 and 7). Numbers at the tops of the boxes are ingestion; numbers inside the boxes are calculated growth; numbers for man are kill rates. Heavy arrows highlight energy flow mediated by arctic cod. 
TABLE 4. Energy flow through middle trophic components in the Lancaster Sound region

\begin{tabular}{|c|c|c|c|c|c|c|c|c|}
\hline \multirow[b]{2}{*}{ Component } & \multirow[b]{2}{*}{ Water body } & \multicolumn{2}{|c|}{ Abundance } & \multirow[b]{2}{*}{ Ingestion $(\mathrm{kJ})$} & \multirow[b]{2}{*}{ Growth $(\mathrm{kJ})$} & \multicolumn{2}{|c|}{ Respiration } & \multirow[b]{2}{*}{ Egestion $(\mathrm{kJ})$} \\
\hline & & No. $\left(\mathrm{m}^{-2}\right)$ & biomass $\left(\mathrm{g} \cdot \mathrm{m}^{-2}\right)$ & & & $\mathrm{g} \mathrm{O}_{2}$ & $(\mathrm{~kJ})$ & \\
\hline Ice amphipods & BS & & $0.005 \mathrm{dw}$ & 1.33 & 0.317 & 0.0432 & $(0.615)$ & 0.399 \\
\hline Herbivorous copepods, 1984 & BS & & $2.178 \mathrm{dw}$ & 5079 & 1828 & 85.6 & $(1219)$ & 2032 \\
\hline Herbivorous copepods, 1986 & BS & & $0.693 \mathrm{dw}$ & 888 & 319 & 15.0 & $(213)$ & 355 \\
\hline Parathemisto spp. & BS/LS & 170 & $0.68 \mathrm{dw}$ & . 66 & 18 & - & (35) & 13 \\
\hline Chaetognaths & BS/LS & 1393 & $1.0 \mathrm{dw}$ & 164 & 46 & - & $(86)$ & 33 \\
\hline Arctic cod & BS & & $0.062 \mathrm{ww}$ & 1.115 & 0.312 & 0.0407 & $(0.580)$ & 0.223 \\
\hline Mertensia ovum & BS & & $0.572 \mathrm{dw}$ & 51.5 & 4.1 & 1.87 & $(34.0)$ & 13.4 \\
\hline Other gelatinous zooplankton & BS & & & & & 20.5 & & \\
\hline Mya truncata, all depths & BS & 10.7 & $\mathrm{dw}$ & 634 & $1.02 \mathrm{~g} \mathrm{dw}(16.2)$ & 25.6 & $(364)$ & 254 \\
\hline Mya truncata, $0-100 \mathrm{~m}$ & BS & 40.8 & 115 & 2411 & $3.89 \mathrm{~g} \mathrm{dw}(61.6)$ & 97.3 & $(1385)$ & 964 \\
\hline
\end{tabular}

${ }^{1}$ Data are given in terms of the units originally measured, with the energy equivalent in kilojoules in parentheses. Data given only in kJ are calculated from the original measurements. All data units are $\mathrm{m}^{-2}$. $\mathrm{yr}^{-1}$ for the water bodies listed. Growth is approximately the amount available to the next trophic level (reproductive products, moults, etc., are not considered). BS = Barrow Strait, LS = Lancaster Sound.

\section{Benthos}

Abundance of the bivalve Mya truncata peaks at $15 \mathrm{~m}$ in Barrow Strait and decreases exponentially down to $80 \mathrm{~m}$ (Fig. 5). $M y a$ is an energetically important component of the system, respiring $25 \mathrm{~g} \mathrm{O}_{2} \cdot \mathrm{m}^{-2} \cdot \mathrm{yr}^{-1}$ (Table 4). The production: biomass $(\mathrm{P}: \mathrm{B})$ ratio calculated from Table 4 is on the order of 0.03 , although this is low by some unknown amount because growth was underestimated and gonadal products were not considered. Robertson (1979) computed correlations between lifespan and $P: B$ ratios for marine benthos, from which we have calculated an expected $P: B$ of only 0.18 for a bivalve with a maximum lifespan of 55 years (the oldest specimen we have aged). $M$. truncata are therefore maintaining a high biomass and growing relatively little.

Bivalves are not only important energetically in the ecosystem; much of the phytoplankton filtered out of the water column may be deposited undigested on the bottom, where it then enters the deposit feeder trophic loop (e.g., eaten by Macoma calcarea). The biomass of filter-feeding clams is highest' between 10 and $30 \mathrm{~m}$ depth (Fig. 5), where phytoplankton productivity and biomass are highest in mid-summer. We found a mean of about $1 \mathrm{mg} \mathrm{O}$ respired per $\mathrm{L}$ of water filtered over the range of clam sizes tested. The filtration rate for $M$. truncata averages $70 \mathrm{~L} \cdot \mathrm{m}^{-2} \cdot \mathrm{d}^{-1}$ or $26 \mathrm{~m}^{3} \cdot \mathrm{m}^{-2} \cdot \mathrm{yr}^{-1}$ for the $0-200 \mathrm{~m}$ zone. At its peak density of $136 \cdot \mathrm{m}^{-2}$ at $15 \mathrm{~m}$ depth, Mya respires $0.9 \mathrm{~g} \mathrm{O}_{2} \cdot \mathrm{m}^{-2} \cdot \mathrm{d}^{-1}$ and filters $0.9 \mathrm{~m}^{3} \cdot \mathrm{m}^{-2} \cdot \mathrm{d}^{-1}$, thereby filtering the equivalent of the entire water column from 0 to 15 $m$ depth every 2-3 weeks. We have observed extensive accumulation of green pseudofeces around Mya truncata siphons when chlorophyll concentrations are high, indicating that much of the phytoplankton filtered out of the water column is deposited undigested on the bottom. Mya, Serripes, Hiatella, and other filter-feeding bivalves are thus acting as sedimenting agents, concentrating organic matter at relatively shallow depths and influencing energy flow patterns, much as has been shown for the mussel Modiolus demissus in salt marshes (Kuenzler, 1961). We predict therefore that bottom respiration rates will be highest in the $10-30 \mathrm{~m}$ range and decrease with increasing depth in the LSR.

The major gaps in Figure 9 are at intermediate trophic levels for most benthic species and all zooplankters except copepods and gelatinous predators. The figures for chaetognaths and Parathemisto are little better than guesses, and there are no data for larvaceans and pteropods, seasonally important members of arctic plankton. In the benthos, we have counted some of the more obvious groups in the camera surveys done for clams. The bivalve Hiatella arctica is a major benthic component (Fig. 5). The large bivalve Serripes groenlandicus averages only $1.7 \cdot \mathrm{m}^{-2}$ throughout Barrow Strait, yet reaches high biomass in some areas (unpubl. data). The bivalve Macoma calcarea, which we are unable to count in the photos, is probably the most abundant clam in Resolute Bay (Welch, unpubl. data); if its energy flow equalled that of $M y a$, bivalve ingestion might surpass that of the zooplankton (Fig. 9). Sea urchins are another abundant benthic species (Fig. 5), and britthe stars are particularly important numerically in deep water (Fig. 5). Other noticeable benthos includes pycnogonids $\left(5 \cdot \mathrm{m}^{-2}\right)$, sea cucumbers $\left(3-4 \cdot \mathrm{m}^{-2}\right)$, terebellid polychaetes $(1-$ $\left.2 \cdot \mathrm{m}^{-2}\right)$, and anemones $\left(1-2 \cdot \mathrm{m}^{-2}\right)$. Note that the observed herbivore consumption in Figure 9 is only about $50 \%$ of plant production, because much of the herbivore energetics is not included.

The paucity of winter data is also a serious gap in the model. For annual species such as the ctenophore Mertensia ovum, high summer biomass peaks cannot be extrapolated throughout the year (Siferd, 1990). Species that live two years or longer, and thus may be quantified adequately in summer, may undergo changes in energetics parameters throughout the year. The winter respiration metabolism of $M$. ovum is $30 \%$ less than in summer (Percy, 1988). Calanus hyperboreus in the Gulf of Maine reduce their weight-specific respiration rate by half in

TABLE 5. Annual composition of copepod populations at Resolute

\begin{tabular}{lcccc}
\hline \hline Species & Year & $\begin{array}{c}\text { Mean adult } \\
\mathrm{dw}(\mathrm{mg})\end{array}$ & $\begin{array}{c}\text { \% total copepod } \\
\text { biomass }\end{array}$ & $\begin{array}{c}\text { \% total copepod } \\
\text { respiration }\end{array}$ \\
\hline $\begin{array}{l}\text { Pseudocalanus } \\
\text { acuspes " }\end{array}$ & 1984 & 0.017 & 71 & \\
$\quad$ " & 1986 & & 32 & 88 \\
Calanus & & & & 57 \\
hyperboreus & 1984 & 3.8 & 13 & 4 \\
" " & 1986 & & 35 & 17 \\
Calanus glacialis & 1984 & 0.8 & 12 & 6 \\
" " & 1986 & & 21 & 17 \\
Metridia longa & 1984 & 0.3 & 4 & 2 \\
$"$ " & 1986 & & 12 & 9 \\
\hline \hline
\end{tabular}


winter (Conover and Corner, 1968), as do C. finmarchicus in the Greenland Sea (Hirche, 1983). Welch and Kalff (1975) found that total benthic respiration in Resolute Bay doubled in August compared with rates in May and June. This is not surprising given the extremely pulsed nature of the primary production input. It suggests that the respiration of long-lived benthic species such as Mya may also fluctuate, as would that of microfauna, changing seasonally with changing particulate input to the bottom.

\section{Higher Trophic Levels}

The most detailed and reliable trophic information for the Lancaster Sound region tends to be at the top and bottom of the food web (Fig. 9; Tables 6 and 7). Population data for bears and ringed seals are relatively good as a result of tagging, aerial survey, and breeding habitat survey efforts during the past two decades (e.g., Kingsley et al., 1985; Smith et al., 1985; Stirling et al., 1975; Hammill, 1987). More uncertainty is associated with narwhal, beluga, harp seal, and walrus data, because detailed knowledge of food habits, feeding ranges, and populations is mostly lacking. Birds that nest in large colonies, such as thick-billed murres, northern fulmars, and black-legged kittiwakes, have been relatively well studied (e.g., Gaston and Nettleship, 1981). Information on more widely dispersed species, such as black guillemots and glaucous gulls (Larus hyperboreus), is sparse or nonexistent. One problem with migratory birds and mammals is that yield and ingestion are often decoupled in space and time, with feeding and growth occurring at a given place and time of year, and with mortality occurring elsewhere at another time. For example, most of the current mortality for thick-billed murres is caused by hunting in Greenland and off Newfoundland (Evans and Kampp, 1991; Elliott et al., 1991). Likewise, narwhal and beluga that feed in the Lancaster Sound region in summer may be harvested in Greenland waters at other times of the year. Determining the rates of ingestion and types of prey taken throughout the year for some of these species, particularly the whales, is not feasible.

Ecological efficiency (EE 5-0 of Kozlovsky, 1968) is equal to the energy passed to trophic level $n+1$ divided by ingestion at trophic level $\mathrm{n}$. The ecological efficiency of ringed seals, the yield to bear and man divided by ringed seal ingestions, is $5 \%$ (Fig. 9). This is similar to the average gross growth efficiency (G/I) of $4.8 \%$ for exploited harp seal populations modeled by Lavigne et al. (1985), suggesting that the ringed seal population of the Lancaster Sound region is being utilized by its two main predators at close to its maximum possible yield. An alternative possibility is that there is a net influx of ringed seals into the LSR from outside the region, although we consider this to be unlikely because polar bears are common throughout adjacent areas.

The impact by a species on the ecosystem may be greater than its apparent energy flow would suggest. For example, the energy flow through glaucous gulls in the LSR must be tiny on a square metre basis (Fig. 9), yet the impact of gulls as predators on eggs and young of colonial seabirds is undoubtedly great (Gaston and Nettleship, 1981). Another example is walrus, which eat less than half the Mya truncata biomass they kill (Welch and Martin-Bergmann, 1990), enriching the scavenger food chain (Oliver et al., 1985) by about $0.3 \mathrm{~g}$ clam biomass $\cdot \mathrm{m}^{-2} \cdot \mathrm{yr}^{-1}$ (Table 6 ).

\section{Arctic Cod}

Within the LSR, arctic cod occurred in two types of distributions. Fish were generally found throughout the year at all locations in a dispersed state. In addition, aggregations (schools) often appeared in nearshore waters in summer. Hydroacoustic estimates of the abundance of dispersed cod in 1985 suggested adult arctic cod were more abundant to the east of Cornwallis Island (Fig. 10) but fish density there was low (0.002$0.004 \cdot \mathrm{m}^{-2}$ ). Assuming a mean size of $28 \mathrm{~g}$ per fish, mean "dispersed" biomass was $0.062 \mathrm{~g} \cdot \mathrm{m}^{-2}$ for areas 1-4 (Table 4), for a total of 6000 tonnes extrapolated to the entire LSR.

Much larger amounts of arctic cod occur in schools. For example, schools in Allen Bay (the next embayment west of Resolute Bay; Fig. 1) on 31 August 1989 contained on the order of 75000 tonnes of biomass. We have found similar aggregations somewhere along the south coasts of Cornwallis and Devon islands in most years (Welch, Crawford, and Hop, unpubl. data).

About 148000 tonnes of arctic cod are consumed annually by the seabirds and mammals in the LSR (Table 8), about 25 times our abundance estimates for "dispersed" arctic cod. It is unlikely that the estimate of demand by birds and mammals is that much in error. It is more probable that our hydroacoustical surveys did not account for most of the arctic cod biomass and that the missing biomass was held in schools. Such aggregations are difficult to quantify because they occur sporadically in space and time, separated by hundreds of kilometres of coastline. It is also possible that schools exist near the bottom in deep water, where they are difficult or impossible to "see" hydroacoustically. The persistent diving by a radio-tagged beluga to a depth of $350 \mathrm{~m}$ in a basin in Barrow Strait (Martin and Smith, 1992) could have been feeding behavior directed at schooling arctic cod.

Given the net current flow eastward through the LSR, arctic cod may also be transported from regions to the north and west; if this is true, the consumption of arctic cod by mammals and birds may have been computed for too small an area. This may also be true for other carnivores feeding on zooplankton transported from the north and west. Some trophic components of the LSR thus may be energy-subsidized by allochthonous organic matter moving into the system.

This analysis corroborates earlier assumptions that arctic cod play a major role in the arctic marine ecosystem (summarized in Davis et al., 1980), both as a consumer and as an agent that concentrates mg-sized particles into energy packets large enough to be eaten efficiently by seals, whales, and birds. Major feeding bouts occur when schools of arctic cod are exploited. We observed a pod of about 500 beluga feeding on dense schools of arctic cod in and near Gascoyne Inlet, 20-23 August 1985, during which time the area covered by the arctic cod schools declined greatly. The whales appeared to enter and feed in Gascoyne Inlet, leave, and return some hours later. At $17 \mathrm{~kg}$ cod ingested $\cdot$ animal $^{-1} \cdot \mathrm{d}^{-1}$ for maintenance, on the order of 34 tonnes of arctic cod were eaten in that $4 \mathrm{~d}$ period, in addition to the consumption of fish by thousands of northern fulmars and hundreds of harp seals. It is difficult to imagine such large whale concentrations finding maintenance rations in the form of dispersed arctic cod at the densities we have observed hydroacoustically (Fig. 10).

In addition to the intra-annual cycle of energy flow caused by pulsed primary production and subsequent respiration, 
TABLE 6. Energy flow through marine mammals in the Lancaster Sound region ${ }^{1}$

\begin{tabular}{|c|c|c|c|c|c|c|c|c|c|c|c|c|c|c|}
\hline \multirow[t]{2}{*}{ A } & \multirow{2}{*}{$\begin{array}{c}\text { B } \\
\text { Distribution, } \\
\text { water bodies }\end{array}$} & \multirow{2}{*}{$\begin{array}{c}\mathrm{C} \\
\text { Area } \\
\left(\mathrm{km}^{2}\right) \\
\end{array}$} & \multirow{2}{*}{$\begin{array}{c}\mathrm{D} \\
\text { Residence } \\
\text { time (d) }\end{array}$} & \multirow{2}{*}{$\begin{array}{c}\text { E } \\
\text { Abundance } \\
\end{array}$} & \multirow{2}{*}{$\begin{array}{c}\text { F } \\
\text { Size } \\
(\mathrm{kg}) \\
\end{array}$} & \multicolumn{2}{|l|}{$\mathrm{G}$} & \multicolumn{2}{|c|}{$\begin{array}{c}\mathrm{H} \\
\text { Ingestion } \cdot \mathrm{m}^{-2} \cdot \mathrm{yr}^{-1}\end{array}$} & \multicolumn{4}{|c|}{$\stackrel{\text { I }}{\text { Yield } \mathrm{yr}^{-1}}$} & \multirow{2}{*}{$\begin{array}{l}\% \text { body wt } \\
\text { eaten daily }\end{array}$} \\
\hline & & & & & & Prey composition & $\%$ & $\mathrm{~kJ}$ & gww & number & tonnes & $\mathrm{gww} \cdot \mathbf{m}^{-2}$ & $\mathrm{~kJ} \cdot \mathrm{m}^{-2}$ & \\
\hline Narwhal & $\begin{array}{l}\text { BS, LS, AI, ES, } \\
\text { NB, PS, PRI }\end{array}$ & 85778 & 75 & 20000 & 854 & $\begin{array}{l}\text { Arctic cod } \\
\text { halibut }\end{array}$ & $\begin{array}{l}75 \\
25\end{array}$ & $\begin{array}{l}1.519 \\
0.506\end{array}$ & $\begin{array}{l}0.279 \\
0.093\end{array}$ & 358 & 306 & 0.0036 & 0.0688 & 2.5 \\
\hline Beluga & $\begin{array}{l}\text { BS, LS, PRI, } \\
\text { WC, PS }\end{array}$ & 79968 & 90 & 12000 & 880 & Arctic cod & 100 & 1.599 & 0.294 & 58 & 37.1 & 0.00046 & 0.0089 & 2.5 \\
\hline Walrus & - & {$[30000]$} & {$[365]$} & {$\left[\begin{array}{ll}1 & 000\end{array}\right]$} & 512 & $\begin{array}{l}\text { Mya } \\
\text { Serripes }\end{array}$ & $\begin{array}{l}85 \\
15\end{array}$ & $\begin{array}{l}{[0.86]} \\
{[0.142]}\end{array}$ & $\begin{array}{l}{[0.329]} \\
{[0.052]}\end{array}$ & 20 & 10.2 & - & & 5.7 \\
\hline Harp seal & $\begin{array}{l}\text { LS, BS, AI, } \\
\text { PS, PRI, WC }\end{array}$ & 88525 & 75 & {$[25000]$} & 106 & Arctic cod & 100 & {$[0.511]$} & {$[0.094]$} & 326 & 34.6 & 0.0004 & 0.0075 & 4.2 \\
\hline Bearded seal & Entire LSR 97697 & - & - & 250 & & various & & - & - & 180 & 45 & 0.00046 & & - \\
\hline Killer whale & ES, AI & - & [20] & 1900 & & Narwhal, other? & & - & - & 0 & 0 & 0 & & 0.6 \\
\hline Ringed seal & Entire LSR 97697 & 365 & 161200 & $36.3\left(1.65 \cdot \mathrm{m}^{-2}\right)$ & & $\begin{array}{l}\text { Arctic cod } \\
\text { Parathemisto. } \\
\text { sympagic amphipods } \\
\text { benthic amphipods }\end{array}$ & $\begin{array}{r}60 \\
25 \\
6 \\
9\end{array}$ & $\begin{array}{l}3.915 \\
1.633 \\
0.389 \\
0.586 \\
6.523\end{array}$ & $\begin{array}{l}0.719 \\
0.354 \\
0.085 \\
0.127 \\
1.285\end{array}$ & $\begin{array}{l}\text { (Man) } 7500 \\
\text { (Bear) - }\end{array}$ & $\begin{array}{r}375 \\
1300\end{array}$ & $\begin{array}{l}0.0038 \\
0.0133\end{array}$ & $\begin{array}{l}0.0737 \\
0.2558\end{array}$ & 5.9 \\
\hline Polar bear & Entire LSR 97697 & 365 & 1758 & $200 \quad\left(0.018 \cdot \mathrm{km}^{-2}\right)$ & & Ringed seal & 100 & 0.256 & 0.0133 & 38 & 11.4 & 0.00012 & 0.0022 & 1.0 \\
\hline
\end{tabular}

${ }^{1}$ Numbers in brackets are crude estimates. See Table 1 for abbreviations of water bodies. Data sources are listed below after each species and column heading.

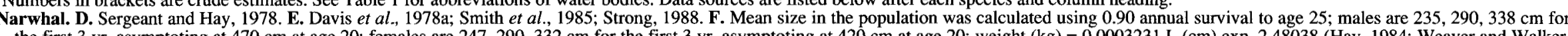

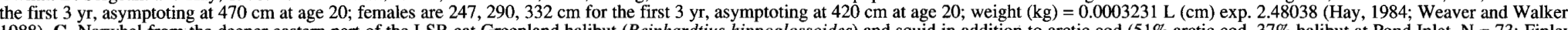

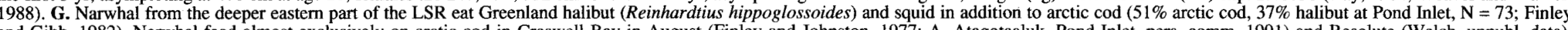

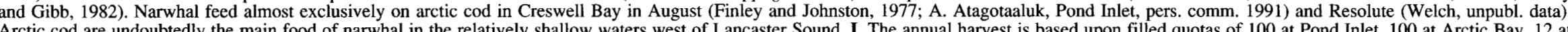

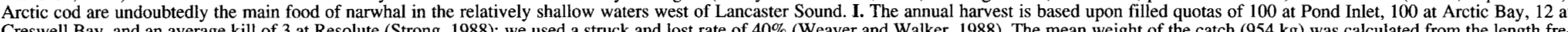

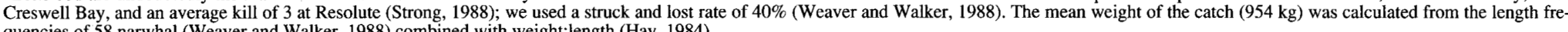
quencies of 58 narwhal (Weaver and Walker, 1988) combined with weight:length (Hay, 1984).

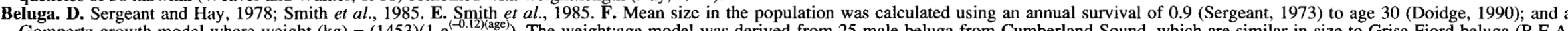

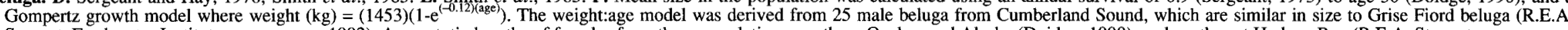

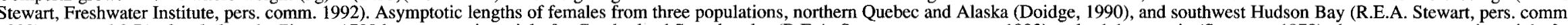

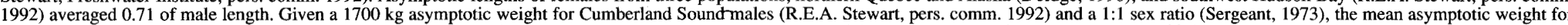

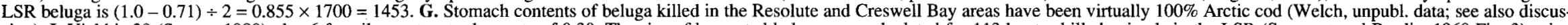

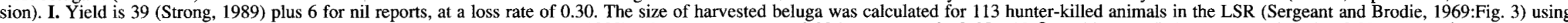
weight:iength equations for Grise Fiord whales (R.E.A. Stewart, pers. comm. 1992), where $\log _{10} \mathrm{wt}(\mathrm{kg})=2.33 \log _{10} \operatorname{length}-3.13 ; \mathrm{N}=10 \%$, and $\log _{10} \mathrm{wt}(\mathrm{kg})=2.32 \log _{10} \mathrm{length}-3.09 ; \mathrm{N}=17 \delta$.

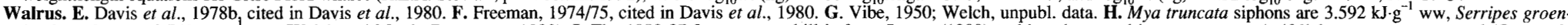

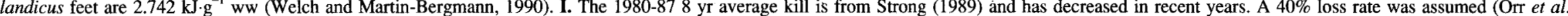
1986).

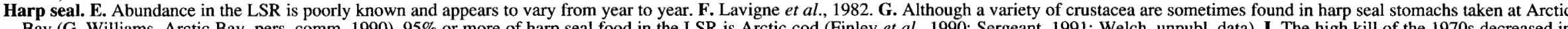

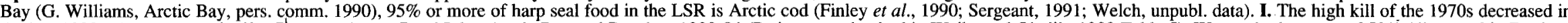

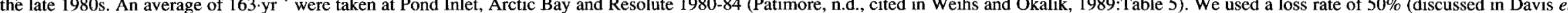

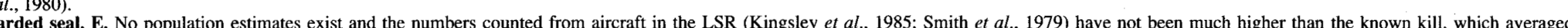

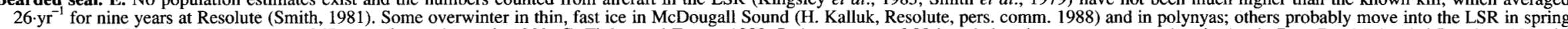

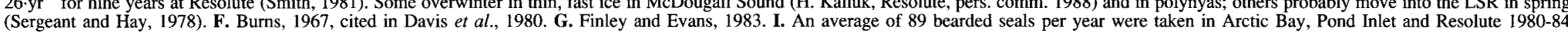
(Patimore, n.d., cited in Weihs and Okalik, 1989:Table 5). The loss rate was assumed to be 50\% (Smith, 1981).

(Patimore, n.d., cited in Weihs and Okalik, 1989:Table 5). The loss ra

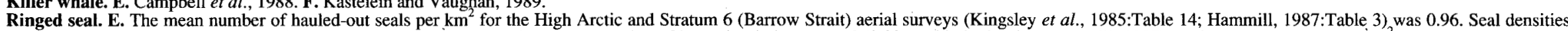

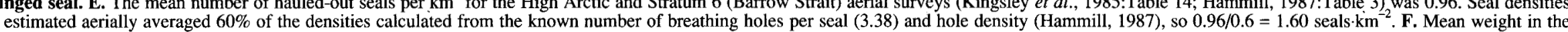

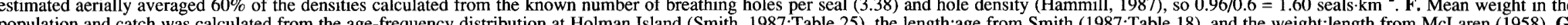

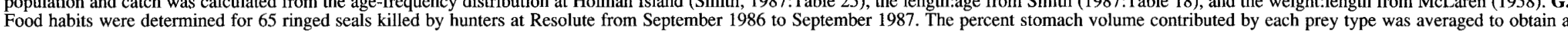


single distribution of prey types for the year. This was $60 \%$ Arctic cod, $25 \%$ Parathemisto spp., $6 \%$ sympagic amphipods, $2 \%$ benthic amphipods, $6 \%$ mysids and $1 \%$ other crustacea (Curtis, unpubl. data), at a mean energy density of $4.61 \mathrm{~kJ} \cdot \mathrm{g}^{-1}$ for crustacea (Percy and Fife, 1981). H. The ADMR was calculated for each of 20 age classes from mean weight at age, multiplied by the fequency distribution, and summed to obtain the mean population ADMR. I. The pre-snowmobile take of ringed seals was on the order of $450 \cdot \mathrm{yr}^{-1}$ for Resolute, $4500 \cdot \mathrm{yr}^{-1}$ for Pond Inlet, and $2300 \cdot \mathrm{yr}^{-1}$ for Arctic Bay (calculated from Bissett, 1967 , 1968), or about 7500 seals annually for the LSR. The annual average for 1980-84 was 371 for Resolute, 3631 for Pond Inlet, and 2421 for Arctic Bay (Patimore, n.d., cited in Weihs and Okalik, 1989:Table 5), for a total of 6423 in the LSR. The seal harvest generally declined (and is probably still declining) during this period. We therefore used an average of 6000 ringed seals as the recent annual catch, divided by 0.8 to account for loss rate (Smith, 1987).

Polar bear. E. Schweinsburg et al. (1982) estimated 1031 bears in about $40000 \mathrm{~km}^{2}$ of LSR waters, or 0.026 bears $\mathrm{km}^{-2}$. Stirling et al. (1978) estimated 1647 bears for their region $\mathrm{F}$, about $160000 \mathrm{~km}^{2}$, or 0.0103 bears $\mathrm{km}^{-2}$. We used the mean of the two estimates. F. The mean weight for 2242 bears at first capture (excluding cubs) was $198.5 \mathrm{~kg}$ (computed from Ramsay and Stirling. 1986:Tables 1 and 2). G. Bears take small numbers of bearded seal and occasionally other marine mammals (Smith and Sjare, 1990), but ringed seals constitute practically all the diet (I. Stirling, Canadian Wildlife Service, Edmonton, pers. comm. 1990). H. Denning females have about $25 \%$ lowered metabolic rates (Watts et al., 1987), but the uncertainty associated with a single standard metabolic equation encompasses this relatively minor potential error. I. The current quota for Resolute, Arctic Bay and Pond Inlet totals 38 bears.

TABLE 7. Energy flow through seabirds in the Lancaster Sound region ${ }^{1}$

\begin{tabular}{|c|c|c|c|c|c|c|c|c|c|}
\hline \multirow[t]{2}{*}{ A } & \multirow{2}{*}{$\begin{array}{c}\text { B } \\
\text { Distribution, } \\
\text { water bodies }\end{array}$} & \multirow{2}{*}{$\begin{array}{c}\mathrm{C} \\
\text { Area } \\
\left(\mathrm{km}^{2}\right) \\
\end{array}$} & \multirow{2}{*}{$\begin{array}{c}\mathrm{D} \\
\text { Residence } \\
\text { time (d) }\end{array}$} & \multirow{2}{*}{$\begin{array}{c}\text { E } \\
\text { Abundance }\end{array}$} & \multirow{2}{*}{$\begin{array}{l}F \\
\text { Size } \\
(\mathrm{g}) \\
\end{array}$} & \multicolumn{2}{|l|}{$\mathrm{G}$} & \multicolumn{2}{|c|}{$\underset{\text { Ingestion } \cdot \mathrm{m}^{-2} \cdot \mathrm{yr}^{-1}}{\mathrm{H}}$} \\
\hline & & & & & & Prey composition & $n \%$ & $\mathbf{k J}$ & $\mathrm{gww}$ \\
\hline Thick-billed murre (adults) & LS, BS & 43643 & 105 & 452000 & 900 & Arctic cod & 85 & 1.496 & 0.2749 \\
\hline Thick-billed murre (juveniles) & LS, BS & 43643 & 75 & 218000 & 900 & $\begin{array}{l}\text { Parathemisto } \\
\text { Sympagic } \\
\text { amphipods }\end{array}$ & 10 & 0.1760 & 0.0382 \\
\hline Thick-billed murre (chicks) & LS, BS & 43643 & - & 169500 & 200 & Arctic cod & 100 & 0.0233 & 0.0043 \\
\hline $\begin{array}{l}\text { Black guillemot (adults) } \\
\text { Black guillemot (juveniles) }\end{array}$ & Entire LSR & 97697 & 105 & $\begin{array}{l}34000 \\
17000\end{array}$ & $\begin{array}{l}400 \\
400\end{array}$ & $\begin{array}{l}\text { Arctic cod } \\
\text { Parathemisto }\end{array}$ & $\begin{array}{l}80 \\
20\end{array}$ & $\begin{array}{l}0.021 \\
0.0054\end{array}$ & $\begin{array}{l}0.0039 \\
0.0011\end{array}$ \\
\hline $\begin{array}{l}\text { Northern fulmar (adults) } \\
\text { Northern fulmar (juveniles) }\end{array}$ & $\begin{array}{l}\text { LS, BS, WC, } \\
\text { AI, PRI }\end{array}$ & 78925 & $\begin{array}{r}105 \\
75\end{array}$ & $\begin{array}{l}320000 \\
160000\end{array}$ & $\begin{array}{l}650 \\
650\end{array}$ & Arctic cod & 100 & 0.556 & 0.1022 \\
\hline $\begin{array}{l}\text { Black-legged kittiwake (adults) } \\
\text { Black-legged kittiwakes (juveniles) }\end{array}$ & LS, BS & 43643 & $\begin{array}{r}105 \\
75\end{array}$ & $\begin{array}{l}200000 \\
100000\end{array}$ & $\begin{array}{l}365 \\
365\end{array}$ & Arctic cod & 100 & 0.336 & 0.0618 \\
\hline
\end{tabular}

${ }^{1}$ See Table 1 for abbreviations of water bodies. Data sources are listed below after each species and column heading.

Thick-billed murre. E. Nettleship and Evans (1985) reported 226.000 breeding pairs in the LSR region, present at the colonies 15 May-1 September (105 d). Immature birds older than one year visit the colonies late in summer, arriving earlier and earlier as they age (Hudson, 1985). Annual adult survival is 0.91 (Hudson, 1985), equalling 40700 birds entering the adult population at age 5. At 0.34 juvenile to adult survival (Hudson, 1985:Table 5.8), this equals 120 000 juveniles required at 0.77 survival per year to give about 41000 birds reaching age 5 , or approximately 218000 juveniles $2-4$ years old on the feeding grounds for an assumed $75 \mathrm{~d}$. This equals an adult:juvenile ratio of about 2:1. 226000 chicks at 0.75 survival to fledging $=169500$ chicks. F. Gaston and Nettleship, 1981. G. Bradstreet and Cross, 1982; Bradstreet and Brown, 1985.169500 chicks require $1100 \mathrm{~g}$ of arctic cod each (Gaston and Nettleship, 1981 ), or 186450 $\mathrm{kg}$ cod, excluding that required for non-surviving chicks and for $2260 \mathrm{~kg}$ egg production (Gaston and Nettleship, 1981; Furness, 1978). This is less than $2 \%$ of the total population energy flow for thick-billed murres during this period.

Black guillemot. E. Nettleship and Evans, 1985; Gaston and Nettleship, 1981. We assumed the same 2:1 adult:juvenile ratio as was calculated for thick-billed murres. F. Harris and Birkhead, 1985. G. Ingestion was calculated as for murres but food habits are poorly known. Intake of chicks was ignored (see murres above).

Northern fulmar. E. Brown et al., 1975. We assumed the same 2:1 adult:juvenile ratio as for thick-billed murres. F. Gabrielsen et al.,; 1988. G. Ingestion was calculated as for murres, ignoring chicks (see murres above). Bradstreet and Cross (1982) found the food of northern fulmars in the LSR to be nearly all arctic cod from a small sample. Our observations suggest that northern fulmars in Barrow Strait eat mostly cod, plus copepods and amphipods, and that they are very opportunistic, resulting in extreme variability of 'stomach contents for birds taken within a few kilometres of each other. Major feeding bouts occur when schools of arctic cod appear in shallow water (Hobson and Welch, 1992).

Black-legged kittiwake. E. Brown et al., 1975. We assumed the same 2:1 adult:juvenile ratio as for thick-billed murres. F. Gabrielsen et al., $1988 ;$ Brekke, 1989. G. Ingestion was calculated as for murres, ignoring chicks (see murres above). Kittiwakes in northern Norway eat almost all capelin (Furness and Barrett, 1985, cited in Erikstad, 1990), which are not present in the LSR. We have assumed black-legged kittiwakes eat only arctic cod in the LSR, which is somewhat in error since they exhibit opportunism similar to that of fulmars, with scattered feeding on large zooplankton, coupled with major feeding bouts on schooling arctic cod.

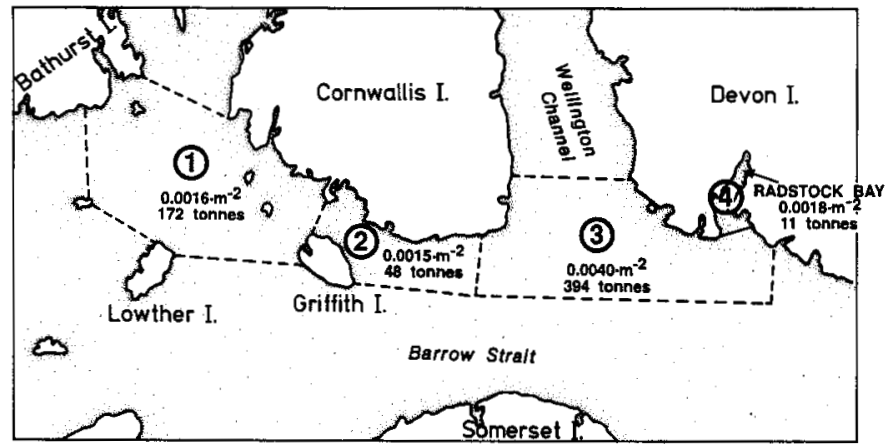

FIG. 10. Abundance of arctic cod in the Resolute area as determined by hydroacoustical surveys. inter-annual variability is also important and has not been assessed in the "static" picture we present here. Arctic cod have shown considerable variability in their year-to-year distribution in the Beaufort (Craig et al., 1982) and Chukchi seas (Quast, 1974). Ringed seals and bearded seals were about twice as abundant in 1974 as in 1975 in the Beaufort Sea, probably related to abnormally heavy ice conditions in 1974, which caused reduced productivity, survival, ovulation rate, and pregnancies (Stirling et al., 1977, 1982). The 1973 and 1974 ringed seal year class strengths were far below the annual mean (Smith, 1987). The distribution of polar bears also varied between years due to the changes in abundance and accessibility of their seal prey. The low seal productivity and availability in 1974 was reflected in a lower survival of 
TABLE 8. Total annual predation on Arctic cod in the Lancaster Sound region (tonnes)

\begin{tabular}{lclr}
\hline \hline Marine mammals & Tonnes & Seabirds & Tonnes \\
\hline Narwhal & 23000 & Thick-billed murres & 12180 \\
Beluga & 23000 & Black guillemots & 380 \\
Harp seal & 8000 & Northern fulmars & 8070 \\
Ringed seal & 70000 & Black-legged kittiwakes & 2700 \\
Total & 125000 & Total & 23330 \\
& Grand Total $\quad 148330$ & \\
\hline
\end{tabular}

polar bear cubs and changes in polar bear distribution in 1975 (Stirling et al., 1975). For the LSR, a twofold interannual variability in phytoplankton production (Table 2) and a threefold interannual range in copepod biomass (Conover, unpubl. data) do not appear to result in marked interannual fluctuations in energy flow through arctic cod, ringed seals, polar bears, or seabirds (Welch, Hobson, and Conover, unpubl. ms.).

\section{GENERAL CONCLUSIONS}

Little significance can be attached to much of the energy flow data synthesized herein because of high variability and the inability to put meaningful confidence limits on most of the data. Nonetheless there are some relatively robust results. First, there is more than adequate primary production to supply the food web supporting sea mammals and birds. Second, major planktonic and benthic components are missing from the analysis, since calculated consumption by the second trophic level is only half of production. Third, our estimates of arctic cod abundance are far too low to account for the production consumed by sea mammals and birds, as discussed earlier. Fourth, marine mammals are consuming much more arctic cod than are seabirds (Table 8 ). Fifth, the consumption of ringed seal production is probably close to the maximum possible, leaving little leeway for increased yield to either polar bears or man. Should ringed seal production be reduced, it should be manifested in bear condition factors and reproductive status. Sixth, food chains supporting higher vertebrates are generally long, with bears occupying a clearly defined fifth trophic level (this has been corroborated by nitrogen stable isotope analysis; Hobson and Welch, 1992). Long food chains help explain the relatively high concentrations of organochlorine contaminants in arctic marine mammals compared with concentrations in water and plankton (Muir et al., 1992).

There are many major data gaps in this trophic analysis of the LSR. Important needs include data on the abundance of most zooplankton and benthos; growth estimates for most invertebrate species; year-round data on respiration rates for all invertebrates; information on arctic cod abundance and distribution; and data on fluxes of allochthonous and autochthonous energy as they are driven by water currents. Better data on birds and mammals - for example, the energy balance of each species in the LSR in summer and the location of mortality throughout the year - will improve the analysis but in some cases may be difficult or impractical to obtain. Last, we note that there is little information on interannual variability, especially as the abundance of a prey affects the subsequent abundance of a predator (the documented change in ringed seals and polar bears in the Beaufort Sea cited above is a notable exception). It would be exciting to be able to predict the year class strengths of birds and mammals from information about food supplies (e.g., arctic cod year class strength) or, even better, from the fluctuations in the physical environment that controls production processes. This will require annual data collection using the same methods in the same locations for a number of years, which is not likely to happen in the present climate of poor funding and fragmented biological oceanographic research in the Canadian Arctic.

\section{ACKNOWLEDGEMENTS}

We thank T. Smith, S. Kasian, R. Hesslein, and two anonymous referees for reviewing the manuscript. J. Walker collected much of the kelp data. L. Harris did most of the zooplankton counts. C. Welch, P. Amarualik, and R. Martin assisted in various aspects of the study, as did many students. In addition to the Department of Fisheries and Oceans, the Polar Continental Shelf Project has provided an important part of our logistical support. Finally we acknowledge the enormous effort expended by numerous researchers to obtain the data we have used herein. Errors in use and interpretation are our own. This is contribution number 11 from the Resolute Marine Laboratory.

\section{REFERENCES}

BAYNE, B.L., HAWKINS, A.J.S., NAVARRO, E., and IGLESIAS, I.P. 1989. Effects of seston concentration on feeding, digestion and growth in the mussel Mytilus edulis. Marine Ecology Progress Series 55:47-54.

BERGMANN, M.A., WELCH, H.E., BUTLER-WALKER, J., and SIFERD, T. 1991. Ice algae production at Resolute and Saqvaqjuac, N.W.T. in the Canadian Arctic. Journal of Marine Systems 2:43-52.

BISSETT, D. 1967. Resolute: An area economic survey. Ottawa: Department of Indian Affairs and Northern Development. $175 \mathrm{p}$.

1968. Northern Baffin Island; an area economic survey. Vol. 1. Ottawa: Department of Indian Affairs and Northern Development (AESR 67-1). $\mathrm{xxii}+209 \mathrm{p}$.

BORSTAD, G.A., and GOWER, J.F.R. 1984. Phytoplankton chlorophyll distribution in the Eastern Canadian Arctic. Arctic 37:224-233.

BRADSTREET, M.S.W., and BROWN, R.G.B. 1985. Feeding ecology of the Atlantic Alcidae. In: Nettleship, D.N., and Birkhead, T.R., eds. The Atlantic Alcidae. London: Academic Press. 264-318.

BRADSTREET, M.S.W., and CROSS, W.E. 1982. Trophic relationships at High Arctic ice edges. Arctic 35:1-12.

BRADSTREET, M.S.W., FINLEY, K.J., SEKERAK, A.D., GRIFFITHS, W.B., EVANS, C.R., FABIJAN, M.F., and STALLARD, H.E. 1986. Aspects of the biology of arctic cod (Boreogadus saida) and its importance in arctic marine food chains. Canadian Technical Report of Fisheries and Aquatic Sciences No. 1491. viii +193 p.

BREKKE, B. 1989. Capability of kittiwake and thick-billed murre to utilize the energy in capelin and arctic cod. Ph.D. thesis, University of Oslo, Oslo, Norway. 64 p. (Translated from Norwegian in Canadian Translation of Fisheries and Aquatic Sciences 5478, 1989.)

BRETT, J.R., and GROVES, T.D.D. 1979. Physiological energetics. In: Hoar, W.S., Randall, D.J., and Brett, J.R., eds. Fish physiology. Vol. 8. Bioenergetics and Growth. New York: Academic Press. 279-352.

BROWN, R.G.B., NETTLESHIP, D.N., GERMAIN, P., TULL, C.E., and DAVIS, T. 1975. Atlas of eastern Canadian seabirds. Ottawa: Canadian Wildlife Service. $220 \mathrm{p}$.

BURNS, T.P. 1989. Lindeman's contradiction and the trophic structure of ecosystems. Ecology 70:1355-1362.

CAMPBELL, R.R., YURICK, D.B., and SNOW, N.B. 1988. Predation on narwhals, Monodon monoceros, by killer whales, Orcinus orca, in the eastern Canadian Arctic. Canadian Field-Naturalist 102:689-696.

CAREY, A.G., Jr. 1985. Marine ice fauna: Arctic. In: Horner, R.A., ed. Sea ice biota. Boca Raton, Florida: CRC Press. 173-190.

CHAPMAN, A.R.O., and LINDLEY, J.E. 1980. Seasonal growth of Laminaria solidungula in the Canadian High Arctic in relation to inorganic and dissolved nutrient concentrations. Marine Biology 57:1-5.

CONOVER, R.J. 1978. Transformation of organic matter. In: Kinne, O., ed. Marine biology. Vol. 4. Dynamics. London: John Wiley and Sons Limited. 221-499. 
CONOVER, R.J., and CORNER, E.D.S. 1968. Respiration and nitrogen excretion by some marine zooplankton in relation to their life cycles. Journal of the Marine Biological Association of the United Kingdom 48:49-75.

CONOVER, R.J., and COTA, G.F. 1985. Balance experiments with arctic zooplankton. In: Gray, J.S., and Christiansen, M.E., eds. Marine biology of polar regions and effects of stress on marine organisms. London: John Wiley and Sons Limited. 217-236.

CRAIG, P.C., GRIFFITHS, W.B., HALDORSON, L., and McELDERRY, H. 1982. Ecological studies of Arctic cod, Boreogadus saida, in Beaufort Sea coastal waters, Alaska. Canadian Journal of Fisheries and Aquatic Sciences 39:395-406.

CRAWFORD, R.E., and FOX, J.K. 1992. Visualization of echo sounder data with a microcomputer. Canadian Technical Report of Fisheries and Aquatic Sciences 1840:iv + $17 \mathrm{p}$.

CRAWFORD, R.E., and JORGENSON, J. 1990. Density distribution of fish in the presence of whales at the Admiralty Inlet landfast ice edge. Arctic 43:215-222

CROSS, W.E., and THOMSON, D.H. 1987. Effects of experimental releases of oil and dispersed oil on arctic nearshore benthos. I. Infauna. Arctic 40:184-200.

CUMMINS, K.W., and WUYCHECK, J.C. 1971. Caloric equivalents for investigations in ecological energetics. Mitteilungen der Internationalen Vereinigung fuer Theoretische und Angewandte Limnologie 18:1-158.

DAVIS, R.A., FINLEY, K.J., and RICHARDSON, W.R. 1980. The present status and future management of arctic marine mammals in Canada. Yellowknife: Science Advisory Board of the Northwest Territories. Report No. $3.93 \mathrm{p}$.

DAVIS, R.A., KOSKI, W.R., and FINLEY, K.J. 1978b. Numbers and distribution of walruses in the Central Canadian High Arctic. Report by LGL Limited for Polar Gas Project, Toronto. 50 p. (Available at Library, Freshwater Institute, 501 University Crescent, Winnipeg, Manitoba R3T 2N6.)

DAVIS, R.A., RICHARDSON, W.J., JOHNSON, S.R., and RENAUD, W.E. 1978a. Status of the Lancaster Sound narwhal population in 1976. Report of the International Whaling Commission 28:209-215.

DOIDGE, D.W. 1990. Age-length and length-weight comparisons in the beluga, Delphinapterus leucas. In: Smith, T.G., St. Aubin, D.J., and Geraci, J.R., eds. Advances in research on the beluga whale, Delphinapterus leucas. Canadian Bulletin of Fisheries and Aquatic Sciences 224:59-68.

ERIKSTAD, K.E. 1990. Winter diets of four seabird species in the Barents Sea after a crash in the capelin stock. Polar Biology 10:619-627.

ELLIOTT, R.D., COLLINS, B.T., HAYAKAWA, E.G., and METRAS, L. 1991. The harvest of murres in Newfoundland from 1977-78 to 1987-88. In: Gaston, A.J., and Elliott, R.D., eds. Studies of high-latitude seabirds. 2. Conservation biology of thick-billed murres in the northwest Atlantic. Ottawa: Canadian Wildlife Service. Occasional Paper No. 69:36-44.

EVANS, P.G.H., and KAMPP, K. 1991. Recent changes in thick-billed murre populations in East Greenland. In: Gaston, A.J., and Elliott, R.D., eds. Studies of high-latitude seabirds. 2. Conservation biology of thick-billed murres in the northwest Atlantic. Ottawa: Canadian Wildlife Service. Occasional Paper No. 69:7-14.

FAY, F.H. 1982. Ecology and biology of the Pacific walrus, Odobenus rosmarus divergens Illiger. Washington, D.C.: United States Fish Wildlife Service. North American Fauna 74. v + 279 p.

FEE, E.J. 1990. Computer programs for calculating in situ phytoplankton photosynthesis. Canadian Technical Report of Fisheries and Aquatic Sciences $1740 . v+27 p$.

FEE, E.J., HECKY, R.E., and WELCH, H.E. 1987. Phytoplankton photosynthesis parameters in central Canadian lakes. Journal of Plankton Research 9:305-316

FINLEY, K.J., and EVANS, C.R. 1983. Summer diet of the bearded seal (Erignathus barbatus) in the Canadian High Arctic. Arctic 36:82-89.

FINLEY, K.J., and GIBB, E.J. 1982. Summer diet of the narwhal (Monodon monoceros) in Pond Inlet, northern Baffin Island. Canadian Journal of Zoology 60:3353-3363.

FINLEY, K.J., and JOHNSTON, W.G. 1977. An investigation of the distribution of marine mammals in the vicinity of Somerset Island with emphasis on Bellot Strait, August-September 1976. Report by LGL Ltd., Toronto, for Polar Gas Project, Toronto. 91 p. (Available at Library, Freshwater Institute, 501 University Crescent, Winnipeg, Manitoba R3T 2N6.)

FINLEY, K.J., BRADSTREET, M.S.W., and MILLER, G.W. 1990. Summer feeding ecology of harp seals (Phoca groenlandica) in relation to arctic cod (Boreogadus saida) in the Canadian High Arctic. Polar Biology 10:609-618.

FISSEL, D.B., LEMON, D.D., and BIRCH, J.R. 1981. The physical oceanography of western Baffin Bay and Lancaster Sound. Eastern Arctic Marine
Environmental Studies Report No. 25. Ottawa: Department of Indian and Northern Affairs. xxxix +293 p.

FISSEL, D.B., LEMON, D.D., and BIRCH, J.R. 1982. Major features of the summer near-surface circulation of western Baffin Bay, 1978 and 1979. Arctic 35:180-200.

FISSEL, D.B., LEMON, D.D., and KNIGHT, D.N. 1984. An oceanographic survey of the Canadian Arctic Archipelago, March 1983. Canadian Contract Report of Hydrography and Ocean Sciences 16. 355 p.

FURNESS, R.W. 1978. Energy requirements of seabird communities: A bioenergetics model. Journal of Animal Ecology 47:39-53.

GABRIELSEN, G.W., MEHLUM, F., and KARLSEN, H.E. 1988. Thermoregulation in four species of arctic seabirds. Journal of Comparative Physiology B 157:703-708.

GALLIVAN, G.J. 1977. Temperature regulation and respiration in the freely diving harp seal (Phoca groenlandica). M.Sc. thesis, University of Guelph, Guelph, Ontario.

GASTON, A.J., and NETTLESHIP, D.N. 1981. Thick-billed Murres of Prince Leopold Island. Canadian Wildlife Service Monograph Series 6. xxvii + $350 \mathrm{p}$.

GORMAN, R.W. 1988. Sea ice characteristics of the Parry Channel. M.Sc. thesis, Carleton University, Ottawa, Ontario. $197 \mathrm{p}$.

GULLIKSEN, B., and LØNNE, O.J. 1989. Distribution, abundance, and ecological importance of marine sympagic fauna in the Arctic. Rapports et Proces-verbaux des Reunions Conseil International pour l' Exploration de la Mer 188:133-138.

HAMMILL, M.O. 1987. Ecology of the ringed seal. Ph.D. thesis, McGill University, Montreal, Quebec. $107 \mathrm{p}$

HARRIS, M.L., and BIRKHEAD, T.R. 1985. Breeding ecology of the Atlantic Alcidae. In: Nettleship, D.N., and Birkhead, T.R., eds. The Atlantic Alcidae. London: Academic Press. 155-204.

HAY, K.A. 1984. The life history of the narwhal (Monodon monoceros L.) in the eastern Canadian Arctic. Ph.D. thesis, McGill University, Montreal, Quebec. $255 \mathrm{p}$.

HIRCHE, H.-J. 1983. Overwintering of Calanus finmarchicus and Calanus helgolandicus. Marine Ecology Progress Series 11:281-290.

HOBSON, K.A., and WELCH, H.E. 1992. Observations of foraging northern fulmars (Fulmarus glacialis) in the Canadian High Arctic. Arctic 45(2): 150-153.

HUDSON, P.J. 1985. Population parameters for the Atlantic Alcidae. In: Nettleship, D.N., and Birkhead,T.R., eds. The Atlantic Alcidae. London: Academic Press. 233-261.

INNES, S., LAVIGNE, D.M., EARLE, W.M., and KOVACS, K.M. 1987. Feeding rates of seals and whales. Journal of Animal Ecology 56:115-130.

IRWIN, B. 1991. Coulometric measurement of primary production, with comparison against dissolved oxygen and ${ }^{14} \mathrm{C}$ methods in a seasonal study. Marine Ecology Progress Series 71:97-102.

JOHANNESSON, K.A., and MITSON, R.B. 1983. Fisheries acoustics. A practical manual for aquatic biomass estimation. FAO Fisheries Technical Paper $240.249 \mathrm{p}$

KASTELEIN, R.A., and VAUGHAN, N. 1989. Food consumption, body measurements and weight changes of a female killer whale (Orcinus orca). Aquatic Mammals 15:18-21.

KINGSLEY, M.C.S., STIRLING, I., and CALVERT, W. 1985. The distribution and abundance of seals in the Canadian High Arctic, 1980-82. Canadian Journal of Fisheries and Aquatic Sciences 42:1189-1210.

KLEIBER, M. 1975. The fire of life: An introduction to animal energetics. Huntington, N.Y.: Robert E. Krieger Publishing Company. 453 p.

KOZLOVSKY, D.G. 1968. A critical evaluation of the trophic level concept. I. Ecological efficiencies. Ecology 49:48-60.

KUENZLER, E.J. 1961. Structure and energy flow of a mussel population in a Georgia salt marsh. Limnology and Oceanography 6:191-204.

LAVIGNE, D.M., BARCHARD, W., INNES, S., and ØRITSLAND, N.A. 1982. Pinniped bioenergetics. In: Mammals in the seas. Vol. 4. Small cetaceans, seals, sirenians and otters. Rome: FAO. Fisheries Series 5:191-235.

LAVIGNE, D.M., INNES, S., STEWART, R.E.A., and WORTHY, G.A.J. 1985. An annual energy budget for north-west Atlantic harp seals. In: Beddington, J.R., Beverton, R.J.H., and Lavigne, D.M., eds. Marine mammals and fisheries. London: George Allen and Unwin Limited. 319-336.

LAVIGNE, D.M., INNES, S., WORTHY, G.A.J., KOVACS, K.M., SCHMITZ, O.J., and HICKIE, J.P. 1986. Metabolic rates of seals and whales. Canadian Journal of Zoology 64:279-284.

LEBLOND, P.H. 1980. On the surface circulation in some channels of the Canadian Arctic Archipelago. Arctic 33:189-197.

LEWIS, P.N.B. 1987. Energetics of the arctic sub-ice amphipod Weyprechtia pinguis. M.Sc. thesis, University of Manitoba, Winnipeg, Manitoba. 91 p. 
LINDEMAN, R.L. 1942. The trophic-dynamic aspect of ecology, Ecology 23:399-418.

LONGHURST, A., SAMEOTO, D., and HERMAN, A. 1984. Vertical distribution of arctic zooplankton in summer: Eastern Canadian Archipelago. Journal of Plankton Research 6:137-168.

MANSFIELD, A.W., SMITH, T.G., and BECK, B. 1975. The narwhal, Monodon monoceros, in eastern Canadian waters. Journal of the Fisheries Research Board of Canada 32:1041-1046.

MARKO, J.R. 1978. A satellite imagery study of eastern Parry Channel. Contractor Report Series 78-5. Institute of Ocean Studies, Patricia Bay, Sidney, British Columbia. 134 p. (Available at Library, Institute of Ocean Sciences, P.O. Box 6000 , Sidney, British Columbia V8L 4B2.)

1982. The ice environment of eastern Lancaster Sound and northern Baffin Bay. Eastern Arctic Marine Environmental Studies Report No. 26. Ottawa: Department of Indian and Northern Affairs. xxv +201 p. + appendices.

MARTIN, A.R., and SMITH, T.G. 1992. Deep diving in wild, free-ranging beluga whales, Delphinapterus leucas. Canadian Journal of Fisheries and Aquatic Sciences 49:462-466.

McLAREN, I.A. 1958. The economics of seals in the eastern Canadian Arctic. Fisheries Research Board of Canada, Arctic Unit Circular 11. 94 p.

McLAREN, P.I. 1982. Spring migration and habitat use by seabirds in eastern Lancaster Sound and western Baffin Bay. Arctic 35:88-111.

MUIR, D.C.G., NORSTROM, R.J., and SIMON, M. 1988. Organochlorine contaminants in arctic marine food chains: Accumulation of specific polychlorinated biphenyls and chlordane-related compounds. Environmental Science and Technology 22:1071-1079.

MUIR, D.C.G., WAGEMANN, R., HARGRAVE, B.T., THOMAS, D.J., PEAKALL, D.B., and NORSTROM, R.J. 1992. Arctic marine ecosystem contamination. Science of the Total Environment [in press].

NAGY, K.A. 1987. Field metabolic rate and food requirement scaling in mammals and birds. Ecological Monographs 57:111-128.

NETTLESHIP, D.N., and EVANS, P.G.H. 1985. Distribution and status of the Atlantic Alcidae. In: Nettleship, D.N., and Birkhead, T.R., eds. The Atlantic Alcidae. London: Academic Press. 54-154.

NORSTROM, R.J., SIMON, M., MUIR, D.C.G., and SCHWEINSBURG, R.E. 1988. Organochlorine contaminants in arctic marine food chains: Identification, geographical distribution, and temporal trends in polar bears. Environmental Science and Technology 22:1063-1071.

ODUM, E.P. 1968. Energy flow in ecosystems: A historical review. American Zoologist 8:11-18.

OLIVER, J.S., KVITEK, R.G., and SLATTERY, P.N. 1985. Walrus feeding disturbance: Scavenging habits and recolonization of the Bering Sea benthos. Journal of Experimental Marine Biology and Ecology 91:233-246.

ORR, J.R., RENOOY, B., and DAHLKE, L. 1986. Information from hunts and surveys of walrus (Odobenus rosmarus) in northern Foxe Basin, Northwest Territories, 1982-1984. Canadian Manuscript Report of Fisheries and Aquatic Sciences 1899. Winnipeg: Department of Fisheries and Oceans. iv $+24 \mathrm{p}$.

PARSONS, J.L. 1977. Metabolic studies on ringed seals (Phoca hispida). M.Sc. thesis, University of Guelph, Guelph, Ontario.

PERCY, J.A. 1979. Seasonal changes in organic composition and caloric content of an arctic marine amphipod, Onisimis (= Boeckosimus) affinis H.J. Hansen. Journal of Experimental Marine Biology and Ecology 40:183-192.

PERCY, J.A. 1980. Studies on factors influencing the respiratory metabolism of an arctic marine amphipod Onisimus (= Boeckosimus) affinis. Canadian Data Report of Fisheries and Aquatic Sciences 240. Winnipeg: Department of Fisheries and Oceans. iv $+70 \mathrm{p}$.

1988. Influence of season, size, and temperature on the metabolism of an arctic cydippid ctenophore, Mertensia ovum (Fabricius). Sarsia 73:61-70.

PERCY, J.A., and FIFE, F.J. 1981. The biochemical composition and energy content of arctic marine macrozooplankton. Arctic 34:307-313.

PIKE, D.G., and WELCH, H.E. 1990. Spatial and temporal distribution of sub-ice macrofauna in the Barrow Strait area, Northwest Territories. Canadian Journal of Fisheries and Aquatic Sciences 47:81-91.

PLATT, T., and IRWIN, B. 1973. Caloric content of phytoplankton. Limnology and Oceanography 18:306-310.

PLATT, T., HARRISON, W.G., HORNE, E.P.W., and IRWIN, B. 1987. Carbon fixation and oxygen evolution by phytoplankton in the Canadian High Arctic. Polar Biology 8:103-113.

PRINSENBERG, S.J., and BENNETT, E.B. 1987. Mixing and transports in Barrow Strait, the central part of the Northwest Passage. Continental Shelf Research 7:913-935.
QUAST, J.C. 1974. Density distribution of juvenile Arctic cod, Boreogadus saida, in the eastern Chukchi Sea in the fall of 1970. Fishery Bulletin 72:1094-1105.

RAMSAY, M.A., and STIRLING, I. 1986. Long-term effects of drugging and handling free-ranging polar bears. Journal of Wildlife Management $50: 619-626$.

REEVES, M.R., and WALTER, M.A. 1978. Nutritional ecology of ctenophores - a review of recent literature. In: Russell, F.S., and Yonge, M., eds. Advànces in marine biology. Vol. 15. New York: Academic Press. 249-287.

ROBERTSON, A.I. 1979. The relationship between annual production: biomass ratios and life spans for marine macrobenthos. Oecologia 38:193202.

SAMEOTO, D.D. 1972. Yearly respiration rate and estimated energy budget for Sagitta elegans. Journal of the Fisheries Research Board of Canada 29:987-996.

1973. Annual life cycle and production of the chaetognath Sagitta elegans in Bedford Basin, Nova Scotia. Journal of the Fisheries Research Board of Canada 30:333-344.

1987. Vertical distribution and ecological significance of chaetognaths in the arctic environment of Baffin Bay. Polar Biology 7:317-328.

SCHWEINSBURG, R.E., LEE, L.J., and LATOUR, P.B. 1982. Distribution, movement and abundance of polar bears in Lancaster Sound, Northwest Territories. Arctic 35:159-169.

SERGEANT, D.E. 1973. Feeding, growth, and productivity of northwest Atlantic harp seals (Pagophilus groenlandicus). Journal of the Fisheries Research Board of Canada 30:17-29.

1991. Harp seals, man and ice. Canadian Special Publication of Fisheries and Aquatic Sciences 114. $153 \mathrm{p}$.

SERGEANT, D.E., and BRODIE, P.F. 1969. Body size in white whales, Delphinapterus leucas. Journal of the Fisheries Research Board of Canada 26:2561-2580.

SERGEANT, D.E., and HAY, K. 1978. Migratory sea mammal populations in Lancaster Sound. ESCOM Report No. AI-21. Environmental-Social Program for Northern Pipelines. Ottawa: Department of Indian and Northern Affairs. ix $+31 \mathrm{p}$.

SIFERD, T.D. 1990. Feeding ecology of the ctenophore Mertensia ovum (Fabricius, 1780) and the natural history of gelatinous zooplankton in Resolute Passage, N.W.T. M.Sc. thesis, Dalhousie University, Halifax, Nova Scotia. 100 p.

SMITH, T.G. 1981. Notes on the bearded seal, Erignathus barbatus, in the Canadian Arctic. Canadian Technical Report of Fisheries and Aquatic Sciences 1042. $\mathrm{v}+49 \mathrm{p}$.

1987. The ringed seal, Phoca hispida, of the Canadian Western Arctic. Canadian Bulletin of Fisheries and Aquatic Sciences 216.81 p.

SMITH, T.G., and SJARE, B. 1990. Predation of belugas and narwhals by polar bears in nearshore areas of the Canadian High Arctic. Arctic 43:99-102.

SMITH, T.G., HAMMILL, M.O., BURRAGE, D.J., and SLENO, G.A. 1985. Distribution and abundance of belugas, Delphinapterus leucas, and narwhals, Monodon monoceros, in the Canadian High Arctic. Canadian Journal of Fisheries and Aquatic Sciences 42:676-684.

SMITH, T.G., SLENO, G.A., and TAYLOR, D. 1979. An aerial survey of marine mammals in the region north of Cornwallis Island, N.W.T. Fisheries and Marine Service Technical Report 837. iv + 14 p.

STEWART, R.E.A., and LAVIGNE, D.M. 1984. Energy transfer and female condition in nursing harp seals Phoca groenlandica. Holarctic Ecology 7:182-194.

STIRLING, I., and CLEATOR, H. 1981. Polynyas in the Canadian Arctic. Canadian Wildlife Service Occasional Paper $45.70 \mathrm{p}$.

STIRLING, I. and McEWAN, E.H. 1975. The caloric value of whole ringed seals (Phoca hispida) in relation to polar bear (Ursus maritimus) ecology and hunting behavior. Canadian Journal of Zoology 53:1021-1027.

STIRLING, I., ANDRIASHEK, D., LATOUR, P., and CALVERT, W. 1975. Distribution and abundance of polar bears in the Eastern Beaufort Sea. Beaufort Sea Technical Report 2. 59 p.

STIRLING, I., ARCHIBALD, R.W., and DeMASTER, D. 1977. The distribution and abundance of seals in the Eastern Beaufort Sea. Journal of Fisheries Research Board of Canada 34:976-988.

STIRLING, I., KINGSLEY, M., and CALVERT, W. 1982. The distribution and abundance of seals in the eastern Beaufort Sea, 1974-1979. Canadian Wildlife Service Occasional Paper 47.25 p.

STIRLING, I., SCHWEINSBURG, R.E., and CALVERT, W. 1978. Polar bear population ecology - arctic islands pipeline route. Final Report to Environmental-Social Program, Northern Pipeline Route. ESCOM Report No. AI-24. Ottawa: Department of Indian Affairs and Northern Development. $93 \mathrm{p}$ 
STRONG, J.T. 1988. Status of the narwhal, Monodon monoceros, in Canada. Canadian Field-Naturalist 102:391-398.

1989. Reported harvests of narwhal, beluga and walrus in the Northwest Territories, 1948-1987. Canadian Data Report of Fisheries and Aquatic Sciences 734. iv \& $14 \mathrm{p}$.

SUBBA RAO, D.V., and PLATT, T. 1984. Primary production of arctic waters. Polar Biology 3:191-201.

VIBE, C. 1950. The marine mammals and the marine fauna in the Thule District (northwest Greenland) with observations on ice conditions in 1939-41. Meddelelser om Grønland 150:1-117.

WATTS, P.D., ØRITSLAND, N.A., and HURST, R.J. 1987. Standard metabolic rate of polar bears under simulated denning conditions. Physiological Zoology 60:687-691.

WEAVER, P.A., and WALKER, R.S. 1988. The narwhal (Monodon monoceros L.) harvest in Pond Inlet, Northwest Territories: Hunt documentation and biological sampling, 1982-1983. Canadian Manuscript Report of Fisheries and Aquatic Sciences 1975 . iv +26 p.

WEIHS, F., and OKALIK, P. 1989. Strategy for the Inuit sealing economy: Baffin region report. Unpubl. report of the Baffin Regional Council, for
Baffin Region Hunter-Trapper Committee, Iqaluit. 160 p. (Available from H.E. Welch, Freshwater Institute, 501 University Crescent, Winnipeg, Manitoba R3T 2N6.)

WELCH, H.E., and BERGMANN, M.A. 1989. Seasonal development of ice algae and its prediction from environmental factors near Resolute, N.W.T., Canada. Canadian Journal of Fisheries and Aquatic Sciences 46:17921804.

WELCH, H.E., and KALFF, J. 1975. Marine metabolism at Resolute Bay, Northwest Territories. In: Proceedings of the Circumpolar Conference on Northern Ecology, Part II. Ottawa: National Research Council. 67-75.

WELCH, H.E., and MARTIN-BERGMANN, K. 1990. Does the clam Mya truncata regenerate its siphon after predation by walrus? An experimental approach. Arctic 43:157-158.

WELCH, H.E., BERGMANN, M.A., SIFERD, T.D., and AMARUALIK, P.S. 1991. Seasonal development of ice algae near Chesterfield Inlet, N.W.T., Canada. Canadian Journal of Fisheries and Aquatic Sciences 48:2395-2402.

WORTHY, G.A.J. 1982. Energy sources of harp seals, Phoca groenlandica, during the post-weaning fast. M.Sc. thesis, University of Guelph, Guelph, Ontario. $100 \mathrm{p}$. 